\title{
Economic Effects of Runs on Early 'Shadow Banks': Trust Companies and the Impact of the Panic of 1907
}

\author{
Carola Frydman* \\ Boston University and NBER \\ Eric Hilt \\ Wellesley College and NBER \\ Lily Y. Zhou \\ Federal Reserve Bank of New York
}

\begin{abstract}
We use the unique circumstances that led to the Panic of 1907 to analyze its consequences for non-financial corporations. The panic was triggered by a shock to New York's trust companies that was unrelated to any major non-financial corporations affiliated with those institutions. Using newly collected data, we find that corporations with close ties to the trust companies that faced severe runs experienced an immediate decline in their stock price, and performed worse in the years following the panic: they earned fewer profits and paid fewer dividends, and faced higher interest rates on their debt.
\end{abstract}

\footnotetext{
*Emails: cfrydman@bu.edu; ehilt@wellesley.edu; and lily.y.zhou@ny.frb.org. We would like to thank Charles Calomiris, Stanley Engerman, Dan Fetter, Dimitris Papanikolaou, Paola Sapienza, Ellis Tallman, and Eugene White, along with participants at the NBER Corporate Finance and Monetary Economics meetings, the Economic History Association meetings, and various seminars, for helpful comments and suggestions. Richard Baker, Asaf Bernstein, Jack Chen, Francis Cho, Hannah Galin, Kimberly Le, Angela Lei, Andrew Marok, Ryan Munoz, Yang Sun, and Veronica Wilson provided excellent research assistance. The views expressed in this paper are those of the authors and do not necessarily reflect those of the Federal Reserve Bank of New York or the Federal Reserve System.
} 


\section{Introduction}

The recent economic crisis has rekindled interest in financial history, in the hope that it may hold insights for modern policy makers. Although the Great Depression has drawn obvious attention, the Panic of 1907 more closely resembles the current crisis, both in the way it unfolded, and in the magnitude of the economic contraction it induced. ${ }^{1}$ The Panic of 1907 originated in New York, with runs on trust companies, the 'shadow banks' of the time. ${ }^{2}$ Less regulated than commercial banks, New York’s trust companies held low cash reserve balances, issued uninsured liabilities, and did not have direct access to a lender of last resort because they did not belong to New York's private clearinghouse association. Early in the crisis, Knickerbocker Trust, one of the largest institutions of its kind, was denied emergency assistance by a syndicate organized by J. P. Morgan and closed its doors. As with Lehman Brothers’ bankruptcy in 2008, Knickerbocker’s closure triggered massive runs on many other trust companies, and spread turmoil throughout the financial system. Uncertainty about the solvency of particular institutions, and the difficulties of organizing emergency lending in the absence of an institutional mechanism for cooperation among the trust companies, plagued efforts to halt the panic. These events led to the imposition of new regulatory frameworks, and ultimately to the establishment of the Federal Reserve System in 1913. ${ }^{3}$

The Panic of 1907 is important not only because of its echoes in the panic that began 100 years later, but also because it presents a unique opportunity to analyze how the contraction in the intermediation provided by shadow banks affected the real economy. Obtaining evidence of this credit supply channel presents an empirical challenge, because financial crises influence the demand for credit, as well as the institutions and relationships facilitating its supply. But the onset of the Panic of 1907 had the important feature that the runs on trust companies were triggered by fears that their directors were involved in a scandal, which had no connection to any major corporation

\footnotetext{
${ }^{1}$ Over the year following the panic, real GNP declined by 11 percent, industrial production contracted by 16 percent, and the unemployment rate almost doubled (Balke and Gordon, 1986; Davis 2004; Romer, 1983). ${ }^{2}$ We follow Gorton and Metrick's (2010) broad definition of shadow banking as a "system [that] performs the same functions as traditional banking” but where "the regulatory structure is light or nonexistent” (p. 261). Similar to modern shadow banks, trust companies experienced rapid growth in the years preceding the crisis, and were important engines of financial innovation (Neal, 1971; Moen and Tallman, 1992).

${ }^{3}$ The extent to which the new legislation actually addressed the causes of the panic is unclear; see Calomiris and Gorton (2000) on the political economy of the regulatory changes enacted in response.
} 
affiliated with those institutions. The resulting financial shock may have been transmitted to the trust companies' clients, who relied on those institutions for financial services. Using newly collected firm-level financial information on all NYSE-listed industrial and railroad corporations from 1900 to 1912, and on the affiliations between those corporations and New York trust companies, we find that the panic had a significant and lasting impact on many corporations with ties to the trust companies that came under the greatest pressure during the panic. ${ }^{4}$

Our analysis proceeds in three steps. First, we establish empirically that much of the variation in deposit losses among the New York trust companies was due to their associations with a handful of men involved in a failed attempt to corner the shares of a mining company. The cornering scheme resulted in a very public scandal. Since the men involved were directors of trust companies, households feared that their deposits may have been threatened, and initiated the runs. Because these runs were caused by an event unrelated to the corporate clients of the trust companies, the problems that often confound efforts to analyze the real effects of financial contractions- that lenders and borrowers may be subject to correlated shocks, or that shocks to borrowers may actually cause shocks to lenders—-seem unlikely to be important in our context.

Our second step obtains a stock market-based assessment of the impact of the shock by analyzing changes in stock prices in reaction to the onset of the runs. We observe affiliations between trust companies and their clients through board interlocks, which were a common part of financial relationships in the early twentieth century. We find that non-financial corporations affiliated with the most severely affected trust companies—-defined as those that were among the top 25 percent in deposit losses-experienced declines in their stock returns that were 50 percent greater than other firms with similar characteristics. Thus, investors perceived that the runs would harm corporations affiliated with the worst affected trust companies.

Finally, we analyze the impact of the shocks to trust companies on the performance of

\footnotetext{
${ }^{4}$ We focus on NYSE-listed firms because they were required by the exchange to produce financial statements. This relatively small number of corporations was responsible for a substantial fraction of economic activity: for 1909, the first year of the federal income tax on corporations, the sample firms accounted for 21.1 percent of total corporate income in the United States, calculated as total reported net income of sample firms (\$758.974 million) divided by total taxable income of all corporations, or \$3.59 billion (Table Ea731-739, Historical Statistics of the United States.) This measure is conservative because the reported net income for many industrials in our sample was after-tax.
} 
affiliated non-financial firms in the years following the panic. Using a difference-in-differences strategy, we find that firms with connections to the more severely affected trust companies experienced lower profitability, paid higher average interest rates on their debts, and paid out dividends at lower rates, relative to similar firms without such connections. The magnitude of the effects was substantial: for small firms, defined as those at the $25^{\text {th }}$ percentile in assets, average interest rates rose by 40 basis points (equivalent to 8.2 percent of the mean interest rate in 1906), and dividend rates fell by 0.6 percentage points (equivalent to 20 percent of the mean dividend rate in 1906). The estimated effects were largest for smaller firms and for industrials, whose collateral was more difficult to value than that of railroads. Thus, our results are consistent with the notion that information asymmetries aggravated the consequences of the contraction of credit intermediation.

A potential source of concern is that our findings may reflect the selection of particular types of firms into relationships with particular trust companies. Our estimation framework controls for time-invariant unobserved characteristics such as firm 'quality,' and we use a variety of strategies to deal with selection on observables. A more difficult problem to address is selection based on unobservable latent characteristics that manifested only in response to a panic, for example if firms more sensitive to a downturn were matched to the trust companies more affected by the panic. Yet in a "placebo test" we find that firms with ties to the most severely affected trust companies in 1907 did not perform worse during an earlier crisis, the recession and financial panic of 1903-04.

This evidence of lasting real effects from the contraction in shadow banking has important implications. The Panic of 1907 was relatively brief, and commercial banks in major cities were able to protect themselves somewhat and halt the spread of contagion by suspending the convertibility of their deposits into cash (Friedman and Schwartz, 1963). But trust companies lacked the legitimacy and institutional clout that enabled commercial banks to suspend — when Knickerbocker Trust closed its doors to depositors and effectively ‘suspended,' the Attorney General of New York immediately filed suit to force them into receivership. ${ }^{5}$ Their status as shadow banks,

\footnotetext{
${ }^{5}$ See Hanna (1931) on the legal response to Knickerbocker's suspension. Suspension by commercial banks violated the law, but was often accepted by regulators when enacted collectively. Gorton (1985) argues for the importance of the suspensions and the issuance of clearing house certificates during panics in the National Banking Era.
} 
and their lack of an institutional framework for coordination or mutual assistance made the panic more severe, and more difficult to contain. Yet perhaps because they were less regulated, trust companies had become quite important in financial markets, and had established strong ties to many non-financial corporations, facilitating access to credit and 'certifying' firms to investors or other lenders. ${ }^{6}$ The crisis apparently disrupted these relationships, and the flows of financial services they had facilitated. Even though the runs on trust companies were controlled within a few weeks through a halting series of privately organized rescue loans, the effects of the shock on corporations with ties to the worst-affected trusts was quite severe, and persistent.

Our results are consistent with two possible channels through which affiliations with trust companies may have had negative consequences for non-financial firms. First, if ties through the board of directors facilitated lending or underwriting, then non-financial firms may have experienced a negative shock to the supply of external financing or the provision of other financial services. ${ }^{7} \mathrm{~A}$ second possibility is that a relationship with a troubled financial institution may have made suppliers, customers, or other lenders of the firm uneasy about the quality of the firm's own assets or operations. That is, the 'certification' role of an affiliation with a financial institution would have been turned into its opposite, as the trust company 'stigmatized' the firm. This mechanism may have been important because of the rumored associations with a scandal in the 1907 panic.

The results of this paper contribute to the large literature on the economic consequences of financial crises. Following Bernanke (1983), a growing body of work has found persuasive evidence that a contraction in credit intermediation has negative effects on access to credit and on the performance of bank borrowers (see, for example, Kashyap, Lamont and Stein, 1994; Peek and Rosengren, 2000; Khwaja and Mian, 2008; Amiti and Weinstein, 2009; Schnabl, 2011; Paravisini,

\footnotetext{
${ }^{6}$ DeLong (1991) presents a strong argument for these roles of financiers on non-financial firms' boards in the early twentieth century US. Although based on post-1908 data, other work has found that the presence of bankers on boards increased firm value and eased financial constraints during normal times (DeLong, 1991; Ramirez, 1995; Cantillo Simon, 1998). See Diamond (1984) for a model of banks as delegated monitors, and Kroszner and Strahan (2001) for the empirical determinants of bank-firm ties among modern American firms. Bank-firm ties may also have costs for the client firms (Weinstein and Yafeh, 1998; Guner, Malmendier and Tate, 2007).

${ }^{7}$ Theoretical work by Bernanke and Blinder (1988), Bernanke and Gertler (1989), Holmstrom and Tirole (1997), and Stein (1998) show that a financial shock to banks may affect real firm outcomes in the presence of market imperfections for banks and firms. An overall contraction in deposits may have exacerbated these frictions during the 1907 panic. Sprague (1908) suggests that most of the deposits withdrawn during the crisis were hoarded as cash outside the financial system.
} 
Rappoport, Schnabl and Wolfenzon, 2011; and Chava and Purnanandam, 2011). This literature has carefully analyzed the transmission of intermediation shocks through traditional commercial banks. In contrast, we study a shock to a shadow banking system, in the context of a historical panic in the United States with many striking similarities to the current financial crisis. The fact that the shock was centered on 'shadow banks' with fragile reputations and no mechanism for coordination likely contributed to the severity of the crisis, and to its propagation to the real economy. Our findings are also related to Fernando, May, and Megginson (2012), who document a negative stock market reaction to the investment banking clients of Lehman Brothers when that firm went bankrupt.

Our paper also contributes to the extensive literature on historical financial crises in the US. Prior work has studied the financial crises of the 1930s (Bernanke, 1983; Calomiris and Mason, 1993; Richardson and Troost, 2009; Carlson, Mitchener and Richardson, 2011; Mladjan, 2012; Ziebarth, 2012), and the panics of the National Banking Era (Calomiris and Gorton, 2000; Wicker, 2000; Hanes and Rhode 2011; Kupiec and Ramirez, 2012). We investigate a historical setting in which connections between specific financial institutions and firms can be identified, and the shock to the financial intermediaries is likely uncorrelated with those faced by the non-financial firms. ${ }^{8}$ Relative to previous historical work, another contribution is that we construct a firm-level dataset with detailed information on firm outcomes and ties to financial institutions. These two features allow us to provide the first systematic evidence of the impact of a financial crisis on firm-level outcomes during the National Banking Era.

The causes and macroeconomic context of the Panic of 1907 received considerable attention in the years following the crisis (Sprague, 1910; Barnett, 1910) and more recently (Moen and Tallman, 1992, 2000; Odell and Weidenmier, 2004; Hansen 2011; and Rogers and Wilson, 2011). We extend this literature by analyzing the microeconomic impact of the crisis, and the consequences of the disruption of the financial system for the real economy.

Finally, some of our findings relate to studies of the role of trust in financial markets (Guiso,

\footnotetext{
${ }^{8}$ Following Khwaja and Mian (2008), most papers on recent financial crises exploit firms' connections to multiple banks to separate credit supply from credit demand shocks. Since this type of data does not exist for earlier periods, a convincing strategy requires both of a shock to financial intermediaries that is uncorrelated to those faced by their clients, and of sufficient micro-level data, making the Panic of 1907 a unique case.
} 
Sapienza and Zingales, 2008) and, in particular, of the effects of impaired reputations of corporate directors. This literature mostly focuses on the consequences of a negative reputational shock on directors' future careers (Agrawal, Jaffe and Karpoff, 1999; Fich and Shivdasani, 2007). In contrast, our results suggest that firms may suffer losses when their directors are perceived to be associated with a scandal not directly connected to the firm.

\section{Historical Background: Anatomy of a Panic}

The events that led to the Panic of 1907 are well chronicled. ${ }^{9}$ Nonetheless, documenting the involvement of specific individuals and institutions helps establish the origins of the shock within the financial system and explains the variation in the intensity of the shock across institutions. Here we present a brief sketch of the onset of the panic, and the historical and institutional context within which it occurred. We then turn to an econometric analysis of the determinants of the trust companies' deposit losses during the panic to establish our claims regarding the causes of the deposit runs more rigorously.

The Panic of 1907 began at a time of instability within American financial markets (Sprague, 1910; Odell and Weidenmier, 2004). In addition, the structure of New York's banking system had recently undergone a significant change, in the form of the rapid proliferation of trust companies, whose total assets approached those of the national banks in size. ${ }^{10}$ Originally created to serve as fiduciaries, trust companies enjoyed broad powers, including the ability to hold corporate equity and debt, to underwrite and distribute securities, and to act as financial agents for corporations (Smith, 1928; Neal 1971). ${ }^{11}$ Incorporated under permissive state laws, they were not subject to the regulations of the National Banking Act, and often specialized in providing financing for corporate investments and acquisitions. One observer noted that the industry's profits were "derived largely from the skill of their officers in financing important combinations and aiding in the creation of new

\footnotetext{
${ }^{9}$ Strouse (1999), Carosso (1987) and Bruner and Carr (2007) present engaging histories of the panic. For early detailed accounts, see Lefevre (1908) and Bayles (1919), and see Moen and Tallman (2000) for a chronology.

${ }^{10}$ In the ten years ending in 1907, trust company assets in New York State had grown 244 percent (from $\$ 396.7$ million to $\$ 1.364$ billion) in comparison to a 97 percent growth (from $\$ 915.2$ million to $\$ 1.8$ billion) in the assets of national banks (Barnett, 1910, p. 235).

${ }^{11}$ As financial agents, trust companies held deposits, negotiated loans, served as trustees for bonds, acted as registrar for securities, and facilitated dividend and interest payments. Contemporary observers noted that firms selected well-known New York trust companies as financial agents "because of the added confidence thus obtainable for the security issues of the corporation” (Smith, 1928, p. 355).
} 
enterprises” (Conant 1904, p. 223). ${ }^{12}$

Trust companies also maintained relatively low cash reserve balances. Whereas the national banks located in New York City were required to hold reserves equivalent to 25 percent of their deposits in cash, New York’s trust companies faced no minimum reserve requirement until 1906, when a relatively weak one was imposed. ${ }^{13}$ Moreover, they were not members of the New York Clearing House Association (NYCHA), the private organization that facilitated clearing and that could provide emergency lending to its members in times of crisis (Gorton, 1985). Trust companies could gain access to the NYCHA by clearing through a member bank, but only if they maintained a minimum level of cash reserves, which most found unacceptably high. ${ }^{14}$ When the panic arose, there was no established mechanism to facilitate cooperation among New York's trust companies, or to provide loans to a trust company that faced a liquidity problem. ${ }^{15}$

To build their reputations, trust company advertisements soliciting deposits prominently featured the names and affiliations of their directors. Many prestigious private bankers, two former U.S. Treasury Secretaries, and numerous executives of major non-financial corporations were among the directors of these enterprises. ${ }^{16}$ But trust companies' reliance on the reputations of their directors became a liability when some of those men were tainted by scandalous rumors. Widespread knowledge of the identity of trust company directors among depositors contributed to the rapid spread of the runs.

\footnotetext{
${ }^{12}$ In the parlance of the time, “combinations” denoted large industrial enterprises that had been formed through the merger of smaller firms that had likely been competitors. On the wave of mergers that ended around 1904, see Lamoreaux (1985).

${ }^{13}$ A 15\% reserve requirement was imposed in 1906, but only one third of it was required to be held in cash. Advocates for New York's trust companies argued that their deposits were like investment accounts and therefore subject to much lower seasonal fluctuations than those of national banks-making a lower level of reserves appropriate (Judd, 1907). Reserve levels became important during the panic, as some of the stronger trust companies advertised their reserve balances daily.

${ }^{14}$ In 1903, the NYCHA adopted the rule that trust companies clearing through its members would have to maintain a cash reserve of $10 \%$ to $15 \%$ after 1 June 1904 (Judd, 1907). At the time trust companies faced no legal reserve requirement at all. Of the 26 trust companies that cleared through NYCHA members, all but two ended their clearing relationships when the rule was imposed (Kilburn, 1904).

${ }^{15}$ In the aftermath of the crisis, trust company insiders mentioned that there was intense "pressure for cooperative action" and that the "lack of organized cohesion" between banks and trusts made the situation much more difficult (Trust Companies, November 1907, p. 751.)

${ }^{16}$ Treasury Secretary Leslie M. Shaw resigned from office in March of 1907 and became the President of the relatively new Carnegie Trust Company; former Secretary Lyman J. Gage was also a director of a trust company; former Vice President of the United States Levi P. Morton was president of Morton Trust Company. Partners of investment banks such as Kuhn Loeb \& Company, and J.P. Morgan \& Company, sat on the boards of several New York trust companies, as did senior executives of U.S. Steel and General Electric.
} 


\section{Onset of the Panic}

The panic was precipitated by events that had no direct connection to any trust company. Instead, they were triggered by a failed attempt in September, 1907 to corner the shares of United Copper Company, a mining concern, which resulted in significant losses for the speculators involved, and the commercial banks that financed them. At the center of the failed speculation were mining entrepreneur Augustus Heinze, along with financiers E. R. Thomas, O. F. Thomas and Charles W. Morse, who had collectively gained control of a series of relatively small banks and used some portion of their resources to finance their ventures. ${ }^{17}$ Many of these commercial banks were members of the NYCHA and therefore potentially had access to a lender of last resort.

On October 16, a run began on the Mercantile National Bank, which was under the control of those men, and which quickly appealed to the NYCHA for aid. The NYCHA provided a loan to Mercantile, and publicly pledged to support the other member banks connected to those men, which included the National Bank of North America. ${ }^{18}$ However, as a condition for this aid, the NYCHA required the resignation of the entire board of directors of Mercantile, and demanded that Morse, the Thomases and Heinze resign from all other clearing banks where they held directorships, declaring that they "shall never again be allowed to do banking business under Clearing House auspices." ${ }^{19}$ The very public support from the NYCHA and the change in management ended the runs on the Mercantile and other member banks connected to those men. However, their expulsions from Clearing House banks severely tarnished their reputations and likely contributed to the perception that they had committed fraud. The public became concerned about the safety of deposits in other institutions to which these men had connections, however minor or insignificant. ${ }^{20}$

Several New York City trust companies had such connections. For example, Charles T. Barney, president of Knickerbocker Trust and director of Trust Company of America, two of the

\footnotetext{
${ }^{17}$ The story of Heinze's exploits in mining, his transition into banking, and the failed speculation in shares of United Copper is presented in McNelis (1968).

${ }^{18}$ On October 20, the NYCHA announced that all of the member banks involved in the copper speculation were solvent, and that a fund of $\$ 10$ million had been raised to provide aid to these institutions (Bayles, 1919). ${ }^{19}$ Bayles (1919: 178).

${ }^{20}$ Lefevre (1908:12) argues that "the ousting of the adventurers from the banks...had left the community so keenly apprehensive that almost anything would have stampeded it.”
} 
largest institutions of their kind in the city, was known to have been involved in earlier business dealings with Morse, and held a board seat with the National Bank of North America. Moreover, Morse, Thomas, and Augustus' brother Arthur Heinze held directorships with other trust companies. The business connections among these individuals, and the board seats they held, were widely reported in the press. ${ }^{21}$

The connections between the men at the center of the United Copper speculation and various financial institutions are illustrated in Figure 1. Morse, Thomas, Barney and the Heinzes held seats on the boards of five trust companies; we identify these institutions as having a direct connection to them. Those five trust companies were, in turn, closely associated with three other trust companies, because they had at least two directors in common. ${ }^{22}$ Those three trust companies are therefore identified as having an indirect connection to Morse, Thomas, Barney and the Heinzes. The degree to which trust companies were associated with those men may have influenced the intensity of the runs they faced during the panic, and we formally test this hypothesis below.

The runs on trust companies began silently around October 16, when Knickerbocker Trust started to face heavy withdrawals. Knickerbocker was one of the few trust companies that chose to maintain sufficient reserves to gain access to the NYCHA through a member of the clearinghouse, the National Bank of Commerce, where Barney was also a director. When Knickerbocker depositors began to withdraw their funds by depositing checks on their accounts in other banks, the National Bank of Commerce was responsible for those checks. Facing a debit balance at the NYCHA of $\$ 7$ million and the prospect of even larger debits, on October 21 the National Bank of Commerce announced that it would no longer act as Knickerbocker's clearing agent. ${ }^{23}$ On that same day, Knickerbocker Trust announced that it had dismissed Barney from the office of its Presidency,

\footnotetext{
${ }^{21}$ See, for example, “New Banking Group Headed by the Heinzes,” 21 January 1907, New York Times; and “C.W. Morse Quits the Banking Field,” 20 October 1907 New York Times.

${ }^{22}$ In addition, the trust companies with Morse, Thomas, Barney and the Heinzes on their boards had only one director in common with three additional trust companies. We focus on trust companies with at least two directors in common to capture stronger connections. The empirical analysis below is robust to the inclusion of a variable that separately identifies trust companies with only one indirect link to these men.

${ }^{23}$ These events are described in Senate Committee on Banking and Currency (1912, p. 1695). The National Bank of Commerce apparently appealed for aid for Knickerbocker from the NYCHA, but was denied (Wicker, 2000). Given Barney's association with National Bank of Commerce, it is possible that some of that bank's debit balance resulted from depositors moving their money to other clearing banks.
} 
because of his "personal position in the directorate of certain institutions recently under criticism," and "in particular because of his connection with Mr. Morse."”24

These events came as a shock to Knickerbocker’s depositors. The end of the clearing relationship meant that other banks would no longer cash the trust company’s checks and, more importantly, that the NYCHA would likely not aid Knickerbocker with their liquidity problems. ${ }^{25}$ The dismissal of Barney, even though it was accompanied by assurances that the firm was in sound condition, may have created the impression that Barney had behaved improperly or used the funds of Knickerbocker to help finance the speculative schemes of Morse. A severe run on the Knickerbocker ensued, and the firm could not withstand the heavy withdrawals without receiving external assistance. None was provided, and on October 22, it was forced to close its doors.

This caused "panic—sheer blind, unreasoning fear" among depositors as they realized that trust companies would be denied emergency assistance from the NYCHA, and "wild rumors circulated” regarding their financial condition. ${ }^{26}$ These rumors often focused on possible connections between trust companies and the men at the center of the failed corner scheme; the chairman of the Trust Company of America went so far as to issue a public statement that his “company had no business relations, directly or indirectly, with Charles W. Morse, as the rumors had intimated."27 Within a few days, all of the trust companies where Thomas, the Heinzes, or Morse held directorships announced their resignations. ${ }^{28}$ By October 23, runs had spread to several other trust companies. ${ }^{29}$ The Trust Company of America, which also had Barney as a director, ultimately endured the largest bank run in American history (up to that time), paying out \$34 million to its depositors. To address the fears of depositors, some trust companies explicitly stated that they

\footnotetext{
${ }^{24}$ The Sun [NY], 22 October 1907, p. 1.

${ }^{25}$ Moen and Tallman (2000) explore the significance of the trust companies' isolation from the NYCHA.

${ }^{26}$ Lefevre (1908, p. 13) and Evening World [NY], 23 October 1907. See also Moen and Tallman (2000: 15052). Several studies have assessed the counterfactual history that would have followed if aid to Knickerbocker had prevented it from failing; see, for example, Sprague (1910) and Friedman and Schwartz (1963).

${ }^{27}$ John E. Borne, quoted in New York Times, 23 October 1907.

${ }^{28}$ New York Times, 20 October, 22 October, and 23 October, 1907.

${ }^{29}$ Evening World [NY], 23 October 1907, p. 1-2.
} 
had no connection to the men associated with the scandal in their advertising. ${ }^{30}$ All trust companies began to call in loans and liquidate assets to build up their cash reserves.

The losses of deposits of the 38 trust companies in New York City between August 22 and December 19 of 1907 are depicted in Figure 2, and detailed summary statistics of these institutions’ balance sheet data are presented in Table A1 of the Data Appendix. ${ }^{31}$ It is worth noting that the size of the trust companies prior to the crisis, measured as their total assets as of June 1907, was

generally uncorrelated with the percentage decline in deposits. All of the trust companies associated with Morse, the Heinzes, Thomas, or Barney lost substantial amounts of deposits, although several others with no apparent direct or indirect connection to these men did as well. ${ }^{32}$ Panel A of Table 1 shows that the deposits in trust companies declined on average by 32 percent, but there were large differences between the firms with and without connections to the men involved in the scandal. The eight trust companies with a direct or indirect connection to those men (as shown in Figure 1) had on average a decline in deposits of 55 percent, whereas the mean decline was only 26 percent for those with no connections.

We analyze the determinants of the percentage change in each New York trust company’s deposits between August and December of 1907 more formally in Panel B of Table 1. In column (1), we regress the change in deposits on separate indicator variables for whether the trusts had direct or indirect connections to the men at the center of the scandal. The estimated parameters are -34 and -22 percent, respectively, and they jointly account for about 40 percent of the variation in the dependent variable. It is of course possible that these effects may have been driven by differences in the financial condition of the trust companies at the time of the crisis. In column (2), we add several balance sheet ratios calculated from the trust companies’ financial statements of June 1907_

\footnotetext{
${ }^{30}$ For example, Bankers Trust's ad in the New York Times from 25 October 1907 lists its directors and their affiliations, and says "Particular attention is called to the personal character and strength of the company's directors."

${ }^{31}$ Since the Superintendent of Banks collected this data quarterly, we use the report dates closest to the panic.

${ }^{32}$ There is some suggestive evidence that financial relationships between the men at the center of the scandal, and trust companies other than those with whom they had a connection through board seats, may also have caused depositors to associate particular trusts with those men. For example, a 1908 criminal indictment claimed that E. R. Thomas had arranged a significant loan from the Italian-American Trust Company (New York Times, 28 February 1908). That firm had no connection to Thomas or his confederates through its board, but nonetheless lost 64 percent of its deposits. Unfortunately, it is impossible to observe such lending agreements systematically.
} 
measures of net worth, cash reserves relative to deposits, the percentage of assets invested in securities, and their overall size-as well as the log of their ages. ${ }^{33}$ The estimated correlations generally have the expected signs, with the firms' net worth and cash holdings having particularly large and positive magnitudes, suggesting that more solvent and liquid trusts faced fewer withdrawals of deposits. Controlling for these characteristics, however, does not diminish the size of the estimated effect of the two indicator variables for association with the tainted bankers.

The available balance sheet information does not capture differences in the depositor clienteles of the trust companies. Hansen (2011) argues that New York's trust companies located in the vicinity of Wall Street received larger deposits from corporations and institutions, whereas those located in uptown Manhattan solicited deposits more aggressively from individuals. He proposes that the uptown firms experienced greater deposit losses because small individual depositors were more likely to participate in runs. In order to address this possibility, column (3) includes an indicator variable for whether the trust company had an uptown headquarters. ${ }^{34}$ Consistent with Hansen's argument, we find that the uptown firms did indeed lose a greater proportion of their deposits. But importantly, controlling for an uptown location does not alter the size of the estimated effect of the indicator variables for the strength of the connection with the men associated with the United Copper corner. Interestingly, the uptown variable does diminish the estimated effect of some of the balance sheet ratios, indicating that the estimated coefficients for these variables in column (2) may have resulted partly from correlations between the financial condition of trust companies and their type of depositor clientele. In sum, our results show that the deposit losses can be regarded in large measure as a response to an association with men involved in a scandal, and thus minimize concerns of reverse causality for the empirical analysis that follows.

\footnotetext{
${ }^{33}$ Trust company advertisements nearly always listed the firms' paid-in capital and surplus (net worth), so this information was easily available to depositors. More detailed balance sheet information was collected by the New York Superintendent of Banks on a quarterly basis and republished in trade publications such as Trust Companies magazine or Bankers Magazine, making it generally accessible as well.

${ }^{34}$ We obtain headquarter locations from Hansen (2011, Figure 1). It should be noted that the distinction between uptown and downtown trusts is unclear in some cases because at least a few companies headquartered uptown such as Knickerbocker had downtown branches, and downtown trusts such as U.S. Mortgage and Trust had uptown branches.
} 


\section{Consequences of the Panic}

During the panic, J. P. Morgan and a few trusted associates coordinated a series of rescues of trust companies, securities dealers, and the City of New York that were instrumental in containing the financial crisis. ${ }^{35}$ Although Knickerbocker Trust was refused aid, emergency assistance was provided to other trust companies beginning on the day following Knickerbocker's closure, and continued well into November. ${ }^{36}$ Ultimately these efforts to provide liquidity prevented additional trust companies from failing, and helped resolve the crisis.

On October 26, in the face of heavy withdrawals from out-of-town banks, the NYCHA issued “clearing house loan certificates" in order to provide liquidity to its members, and New York’s commercial banks soon after suspended the convertibility of their deposits into currency. Full convertibility of deposits by the nation’s banks was not restored until January 1908. The suspension made important transactions more difficult (James, McAndrews and Weiman, 2011), but likely halted the spread of the banking panic and averted a total collapse of the banking system, as in 1930-33 (Friedman and Schwartz, 1963). Faced with a crisis, New York’s commercial banks had access to an institutional mechanism for coordination and mutual assistance, and made use of it.

Trust companies did not have access to similar mechanisms. The contraction of lending that occurred during the panic in New York was heavily concentrated within trust companies. Prior to the panic, the aggregate volume of New York trust company loans was similar to that of New York's national banks. Between August and December of 1907, total loans at trust companies contracted by \$247.6 million, or 37 percent (Moen \& Tallman, 1992). In contrast, the loans of national banks in New York actually rose by 8.8 percent during the same period (Sprague 1910: 300). Contemporary observers noted the consequences: "It is obvious that every trust company is protecting itself to the full extent of its powers, and the small borrowers, however solvent, necessarily suffer at such a

\footnotetext{
${ }^{35}$ In late October, 1907, the U.S. Treasury made a series of deposits in the major national banks in New York, which helped fund some of this lending. Nonetheless, much of the lending to trust companies was financed by commitments from the stronger trust companies, and organized by Morgan.

${ }^{36}$ Knickerbocker's board claimed they had been promised aid (New York Tribune, 22 October 1907, pg. 1). However, Morgan decided that aid should be conditional on the solvency of the firm. Since his associates could not determine whether the firm was solvent in the few hours they had while the firm faced an intense run, aid to Knickerbocker was denied, and the firm was forced to close.
} 
time.”37 The man brought in to serve as president of the Hudson Trust Company after E. R. Thomas resigned, testifying in a subsequent civil trial, was more specific: "As to the general effect upon credit of manufacturing or industrial companies, it very considerably restricted their operations. They were unable to borrow money and were compelled to ask assistance from their creditors and trade was very much depressed.",38

Did the corporations affiliated with trust companies lose access to lending during the crisis? Unfortunately, few systematic records of the identities of borrowers from trust companies or other financial intermediaries survive from this period to quantify the magnitude of lending relationships. Contemporary accounts from journalists did mention loans of particular trust companies to corporations represented on the trust companies' boards. ${ }^{39}$ Moreover, the surviving records of a major New York trust company from a somewhat later period indicate that it did indeed lend substantial amounts to the companies represented on its board. ${ }^{40}$ If that company's experience is at all representative of lending patterns in 1907, it is possible that firms affiliated to trust companies would have faced significant contractions in lending during the panic.

\section{Data on Non-financial Companies and their ties to Banks and Trust Companies}

All of the data utilized in the empirical analysis were hand-collected for this paper. In this section we present a brief description of the sources and methods used in the creation of the dataset, while the Data Appendix provides more complete details.

We identify connections between trust companies and non-financial firms by the presence of board interlocks. To observe board connections, we collect the names of all directors and officers of

\footnotetext{
${ }^{37}$ Wall Street Journal, 24 October 1907, p. 4.

${ }^{38}$ E. R. Chapman (1910: 332-33).

${ }^{39}$ For example, a description of the operations of Produce Exchange Trust Company, which subsequently failed, mentioned significant loans to officers and directors (New York Times, 3 September 1899).

${ }^{40}$ Between 1916 and 1919, when it had become an enormous institution with total resources approaching \$200 million, between 3.5 and 9.8 percent of the value of Farmer's Loan and Trust Company's loans were made to firms represented on their board, or to their directors. In addition, between 4.9 and 15.3 percent of the securities held by this trust company were issued by firms represented on their board. As the oldest and largest of the trust companies in the city, in a later era of more stringent regulations, these numbers are likely lower than they would have been for the younger and more aggressive trust companies back in 1907. (Report of Examination Records, Farmer's Loan and Trust, Series 07, Vault Item 754 00, Shelf 4A, Citigroup Archives).
} 
all NYSE-listed industrials and railroads as reported in Moody's Manuals of Railroads and Corporation Securities, and obtain lists of directors of commercial banks and trust companies from the Rand McNally Bankers’ Directory. Cross-referencing the names of bankers with those of corporate directors enables us to identify the presence of trust company directors on boards of nonfinancial firms. We describe our matching procedure and the alternative sources we have used to verify its accuracy in the Data Appendix. While board interlocks signified close relationships between financial and non-financial firms at that time, one important question is whether the men generating these connections were primarily bankers or industrialists. ${ }^{41}$ To the extent that the principal affiliations of directors can be reliably classified, we find that the individuals creating interlocks were primarily industrialists, railroad executives, or men best described as 'capitalists' sitting on trust company boards, rather than men strictly defined as bankers sitting on non-financial company boards. ${ }^{42}$ The nature of these interlocks suggests that the affiliated financial institutions were indeed important for the provision of credit or other financial services.

For the accounting data on non-financial firms, we construct a comprehensive dataset of all NYSE-traded industrial companies and railroads from various Moody's Manuals, which provide annual firm-level data obtained from annual reports. The sample includes all industrial companies and railroads with common or preferred stock listed on the NYSE that reported an income statement and balance sheet in 1906, a total of 125 firms. We search for financial information for each available year from 1900 to 1912. Except when explicitly stated, we restrict most of our analysis to the period 1903-1912, when accounting information is available for most of the firms in our sample.

Unfortunately, the quality of financial reports varied considerably across firms. Beginning around 1905, the financial statements of railroads were of relatively high quality and reasonably consistent across firms. ${ }^{43}$ The industrials, however, were altogether a different matter. Although the

\footnotetext{
${ }^{41}$ It is possible that trust companies provided financial services to non-financial firms in our sample without a board interlock. However, this measurement problem will lead us to underestimate our results.

${ }^{42}$ Principal affiliations were recorded from the Directory of Directors for the City of New York for 1906 or by using various biographical sources. Among the 88 unique interlocks between a trust company and a nonfinancial firm in 1907, only 9 were created by individuals whose primary affiliation was with a commercial bank or trust company, and another 23 were created by partners of investment banks. Industrialists, railroad executives, and capitalists account for most of the balance.

${ }^{43}$ The 1906 Hepburn Act required railroads to submit detailed financial reports to the Interstate Commerce Commission; the initial 1906 reports presented data for 1905.
} 
NYSE required listed firms to publish financial statements, it did not specify the contents of the required statements, and many firms took great license in their interpretation of the requirement. The contents of balance sheets varied considerably, and relatively few industrial firms presented much detail in their income statements. ${ }^{44}$ Even less common was information on capital expenditures or investment. We therefore focus the analysis on profitability ratios and dividend rates, which can be calculated for nearly all NYSE firms, and average interest rates on bonded debt, for which sufficient data is available for a smaller but still substantial number of firms. In order to reduce the influence of outliers, we trim all accounting variables at the top and bottom one percent.

Our panel dataset contains annual observations of the financial measures, as well as data on the companies' boards and their interlocks with financial institutions obtained at two-year intervals. Tables 2 and 3 present summary statistics. Column (1) of Table 2 reveals that in 1907 NYSE-listed non-financial companies had extensive connections to financial intermediaries; the average firm in the sample had nearly 4 trust company directors on its board, as well as 1.5 directors from New York’s six major commercial banks. ${ }^{45}$ Railroads and other transportation enterprises made up 56 percent of the sample, with the others mostly engaged in manufacturing.

Column (2) of Table 2 reports the difference between firms that were affiliated with at least one of the trust companies that was most severely affected during the panic, and firms that had no such affiliation. Throughout the analysis that follows, we designate as the differentially "affected trust companies” those that were among the top 25 percent in deposit losses. ${ }^{46}$ Among the 125 nonfinancial firms in our sample, 61 had a director in common with one of those trust companies. Firms affiliated with affected trust companies had larger boards, were more likely to be railroads, and had more extensive connections to financial institutions, with 2.7 more trust company directors on their boards, and nearly one more director from a major New York commercial bank. We also find that firms connected to affected trusts were older, and did not differ in the ratio of its retained earnings to

\footnotetext{
${ }^{44}$ Sivakumar and Waymire (1993), and Barton and Waymire (2004) analyze the content of early financial statements.

45 These six banks alone accounted for about three fourths of all net deposits that other banks made in New York City's national banks (Sprague, 1910).

${ }^{46}$ The results presented below are robust to alternative definitions of the group of differentially affected trust companies. For example, focusing on the top 20 percent of deposit losses strengthens the findings, while results are slightly weaker when using the top 30 percent.
} 
total common equity, which is an alternative measure of the stage of a firm's life cycle (DeAngelo, DeAngelo and Stulz, 2006). Thus, it does not appear that weaker or less established firms were more likely to have relationships with the financial institutions that came under the greatest pressure during the panic.

Another potential concern is that firms with worse disclosure of financial information or weaker corporate governance maintained associations with the affected trust companies. As a proxy for the quality of disclosure, we calculate the number of lines of items on the firm's balance sheet (McCartney and Arnold, 2002). Perhaps as a result of their extensive connections to financial institutions, firms affiliated with the worst affected trust companies published financial statements that were of substantially higher quality (nearly 4 additional lines, relative to a mean of 21). To identify differences in corporate governance, we measure the presence of insiders (defined as current and past officers) on a firm's board, which is generally used as evidence of weak monitoring by the board (see Adams, Hermalin and Weisbach, 2010, for a literature review). Firms affiliated with affected trust companies had slightly fewer insiders on their board, although the difference is not statistically significant.

Table 3 summarizes the financial characteristics of the NYSE-listed companies prior to the onset of the panic in 1906. Since the fiscal year end varied across firms, throughout the analysis that follows we assign to 1906 the financial information corresponding to fiscal years ending from July of 1906 to June of 1907 (see Data Appendix for further details). Column (1) reveals that the firms in our sample were very large enterprises, with an average value of total assets of about $\$ 72.6$ million. ${ }^{47}$ The average leverage ratio, defined as bonded debt divided by total assets, was 0.29 , and they held about three percent of their assets in cash. We calculate two measures of profitability: Return on Assets (ROA), defined as net income divided by total assets, and Return on Equity (ROE), defined as net income divided by common shareholders' equity. These were 0.04 and 0.08 on average. The average firm paid out about 3 percent of its book value in common dividends, and faced an average interest rate, measured as interest expense divided by bonded debt, of 4.8 percent.

Table 3 also investigates whether these financial characteristics were different between firms

\footnotetext{
${ }^{47}$ In dollars of 1906. As most of the accounting data we analyze are ratios, we utilize nominal values.
} 
affiliated with the affected trusts and other firms. Column (2) shows that profitability measures, dividends and interest rates were similar across groups. However, the affiliated firms were larger, more levered and had lower cash holdings. Reassuringly, there does not seem to have been differential trends in these characteristics between the two groups of firms in the years preceding the panic. Column (3) presents the estimated coefficient from separate regressions of each outcome variable on an indicator variable for an affiliation with an affected trust company interacted with a time trend using annual data from 1903-1906. ${ }^{48}$ None of the estimated differential trends are large in magnitude or statistically significant, indicating that the two groups of firms were not evolving along different paths in the years prior to the panic.

\section{The Effect of the Panic on Non-Financial Firms}

A preliminary indication of the significance of the panic for firms affiliated with affected trust companies is found in Figure 3, which presents the share of all non-financial company board seats held by New York trust company directors. In the years 1907 through 1913, the proportion of all board seats held by the directors of the most severely affected trust companies fell from 6.2 percent to 0.1 percent. The board seats held by directors of all New York trust companies fell far less in relative terms, from 29.0 to 23.2 percent; most of this decline was actually due to the fall in seats held by the most affected trusts. ${ }^{49}$ The widespread severing of these relationships is consistent with the notion that firms had to turn elsewhere for lending or 'certification' following the panic.

Before proceeding with the empirical analysis, it should be noted that the effects of an affiliation with an affected trust during the panic were likely to be heterogeneous (Bernanke, 1983). Firms with substantial collateral whose value was easily verified, or with well-established reputations, should have suffered less than other firms, as they would have had an easier time

\footnotetext{
${ }^{48}$ These regressions also include year and firm fixed effects.

${ }^{49}$ Over this period, the total number of trust companies declined from 38 in 1907 to 33 in 1911 and 28 in 1913 , due mostly to consolidation in the industry. The number of the affected trust companies still existing as independent entities fell from 8 in 1907 to 7 in 1911, and 4 in 1913.
} 
obtaining alternative sources of lending..$^{50}$ As there was considerable variation in the size, age and reputation of the firms listed on the NYSE at the time of the panic, we expect the effects of the contraction in financial intermediation to differ among the firms in our sample. In our empirical specifications, we explicitly account for this heterogeneity using interaction terms with firm size. Firm size will likely capture the extent to which a firm's reputation was well known among lenders and investors, as larger firms would have been more likely to have raised substantial sums from the capital markets over the years prior to the panic.

Results: Stock Market Event Study

We begin by analyzing changes in the common stock returns of NYSE-listed firms around the onset of the panic. The stock market suffered significantly during the crisis, losing about 25 percent of its value from October to November. However, the decline in stock market value varied considerably across firms. If investors perceived that the losses of deposits and reputations among the trust companies would adversely impact their non-financial clients, we should observe a larger decline in the stock prices of firms connected to those trust companies relative to other firms.

As a starting point, we create equal-weighted portfolios of weekly industry-adjusted returns by grouping firms according to their size and their connections to affected trusts. ${ }^{51}$ We index the portfolios to their initial value about a month prior to the panic, and we cumulate them until the end of the year. Figure 4 shows that all portfolios followed a similar trend until October 18, around the time the run on Knickerbocker started. In the following week, the returns on small firms connected to affected trusts plummeted, and had not recovered by the end of the year. ${ }^{52}$ In contrast, the other

\footnotetext{
${ }^{50}$ This argument suggests that the firms in our sample, some of the largest and best-established enterprises in the United States, were among those firms least likely to suffer as a result of the shock to the trust companies. ${ }^{51}$ We define firms as small if their log level of assets was below the median for the firms with non-missing returns on 25 October 1907, the sample that is the main focus in the event study analysis. Returns are equalweighted due to the small number of firms in each portfolio, particularly towards the end of the sample period. ${ }^{52}$ Contemporary observers noted the differential negative performance of the shares of small companies affiliated with the worst-affected trusts as the panic unfolded. For example, October 22, the day of Knickerbocker's suspension, was described by one journalist as a day of "severe liquidation" on the stock market, and among the "heaviest sufferers" were small firms "in which the Thomas interests have been prominent" or which had been associated with institutions connected to Charles W. Morse. New York Times, 23 October 1907.
} 
three portfolios did not suffer significantly during the depositor runs, and returned to their pre-panic level by the end of December.

To perform a more rigorous analysis of the market reaction in the weeks surrounding the run on Knickerbocker, we employ an event study methodology. For each firm in the sample, we calculate cumulative industry-adjusted weekly returns over a window of weeks $[-k, k]$ centered at the onset of the panic. ${ }^{53}$ Since no high-frequency data on stock prices and dividend payouts are readily available for our period, we collect all necessary information from The New York Times. We discuss the data sources, variable definitions and methodology in detail in the Data Appendix. As securities markets were relatively illiquid early in the twentieth century, our data contain cumulative returns for about 68 percent of the firms in the sample, perfectly split between firms with and without connections to affected trusts.

Our empirical strategy consists of estimating:

$$
\begin{aligned}
& \text { Ind. }- \text { Adj. Cum. Return } i=\alpha+\beta_{0} \text { Affectedtrust }{ }_{i}+\beta_{1} \text { Affectedtrust }_{i} \times \text { logassets } 06_{i}+ \\
& +\beta_{2} \text { logassets } 06_{i}+\delta X_{i}+\varepsilon_{i}
\end{aligned}
$$

where Affectedtrust $t_{i}$ is an indicator equal to one for firms with at least one director from one of the trusts among the top 25 percent in deposit losses; logassets06 is the log level of assets in 1906, measuring the size of firms prior to the panic; and $X_{i}$ includes firm characteristics prior to the panic that may affect returns, such as being a railroad. If the market perceived that connections to an affected trust company through board interlocks were detrimental because of disruptions in access to credit or harm to the firm's reputation, we should find a negative overall effect on the firm's return $\left(\beta_{0}<0\right)$. Since the consequences of these connections were likely to be heterogeneous, the interaction term between affected trust and log assets captures the differential effects for firms of different sizes. We expect to find that larger firms connected to affected trusts had higher returns during the panic than smaller firms with similar connections $\left(\beta_{1}>0\right)$.

\footnotetext{
${ }^{53}$ Our strategy diverges from the standard event study methodology because we cannot calculate abnormal returns as the difference between the actual return and the return predicted from a market model. Estimating such a model would require collecting weekly prices and dividend information from primary sources for about four years prior to the panic, an exceedingly large data collection effort. Our strategy is closer to a marketadjusted-return model, which assumes that $\alpha=0$ and $\beta=1$ for all shares (Campbell, Lo and MacKinlay, 1997). The lack of extensive information on stock returns prior to the panic also limits our ability to adjust the standard errors using the pre-period variance in returns.
} 
Ideally, we would like to study the stock market reaction on Tuesday October 22, 1907, when Knickerbocker failed. Since our data contain only end-of-week prices, we center the event on the closest day available after the failure, Friday October 25. Panel A of Table 4 presents differences in means for industry-adjusted returns cumulated from one week prior to one week after the run on Knickerbocker. Firms with connections to affected trust companies saw a decline in returns of about three percent relative to their industry peers, but market values increased by about two percent for non-connected firms. Dividing the sample between large and small firms reveals that small firms account for this difference.

Panel B of Table 4 presents regressions of firms' market valuations as the runs unfolded. We begin by analyzing the cross-sectional variation in cumulative returns that are not industry-adjusted, for a one-week period around October 25. Cumulating returns helps address the possibility of anticipation of the effect, particularly if investors perceived the consequences of a tightening of credit or loss of reputation for non-financial firms around the run on the Mercantile National Bank. We find that the panic had a significant differential negative effect on the returns of firms connected to affected trusts. The estimates of $\beta_{0}$ and $\beta_{1}$ are statistically significant and have the expected signs. For a firm of median size, cumulative returns on the week around the panic were -6.7 percentage points $(=-1.061+[0.054 \times 18.29])$ lower for a firm connected to an affected trust company than for a non-connected firm of similar size. These are sizable effects: a median-sized industrial firm, for example, experienced a loss in market value that was 50 percent higher than the reduction in value for similar firms solely based on its ties to affected trust companies. ${ }^{54}$ As expected, the magnitude of the effect was heterogeneous. Firms in the $25^{\text {th }}$ percentile of the assets distribution experienced a larger decline in returns of $-0.101(-1.061+[0.054 \times 17.64])$ due to ties to affected trusts relative to similar firms.

We next analyze industry-adjusted returns, to address the potential concern that firms within a given industry may have faced common shocks as the crisis evolved. The results are unchanged by this transformation (column 2). In column (3) we include many of the firm characteristics that

\footnotetext{
${ }^{54}$ More precisely, given our estimated coefficients, the ratio of the predicted return for a median-sized industrial firm connected to an affected trust to the predicted return for a similar non-connected firm is 1.50.
} 
differed across firms with and without connections to affected trusts, such as the total number of trust companies connected to the firm, the number of board seats held by directors of major commercial banks, the book level of leverage in 1906, and the cash to assets ratio in the same year. None of these characteristics affect the estimated difference in cumulative returns relative to industry peers. Finally, column (4) shows that the results are robust to extending the event window to the two-week period surrounding the run on Knickerbocker.

Whether because of reduced access to lending or a loss in reputation, these results indicate that smaller firms connected to affected trust companies saw their stock prices fall substantially at the onset of the panic. Since our strategy compares the cross-sectional differences in returns, one concern is that the results may not be specific to the financial crisis-perhaps these firms generally performed worse. As a "placebo" test, we replicate our analysis of one-week cumulative returns centered at a fictitious event date as early in advance of the panic as our price data allows. As shown in column (5), we find no statistical differences in returns when centered on September 13, 1907, and the magnitudes of the estimated coefficients, both for the "affected trust" dummy variable and for its interaction with initial firm size, are much smaller and have the opposite sign than during the panic. These results are quite reassuring as they suggest that firms connected to affected trusts did not have lower cumulative returns in general relative to the non-connected firms.

\section{Results: Firm Performance}

The event study reveals an immediate effect on market valuations for firms with ties to the trust companies that came under acute pressure as the panic unfolded, but these results do not shed much light on the medium-run effects of the interruption of credit intermediation, beyond the fact that the market expected them to be substantial. We next study the effects of the panic by analyzing the accounting performance of non-financial firms using our panel dataset from 1903 to 1912, which contains 125 firms with accounting information both before and after the panic. ${ }^{55}$

\footnotetext{
55 The actual number of firms varies slightly across specifications since the accounting information is missing for some firm-years for some variables of interest.
} 
Before proceeding to the regressions, Figure 5 presents the annual differences between firms with and without board interlocks with affected trusts in 1907, for the dependent variables of interest, as estimated from regressions with firm fixed effects. ${ }^{56}$ The figure provides a simple illustration of any trends in the differences over time, as well as the timing of any changes associated with the panic. Quite reassuringly, the lines are relatively constant prior to the panic, and they change slope at the time of the panic, or in the following year. Thus, it is unlikely that any estimated effect in the regression analysis would be the result of preexisting differential trends in the dependent variables between firms with and without ties to affected trusts. ${ }^{57}$

The upper panel of the figure shows that, if anything, the profitability of firms affiliated with affected trusts was rising in the years prior to the panic relative to other firms, and then collapsed in 1907 and 1908, before recovering somewhat in 1909 and 1910. The lower panel provides some insight into the causes of this fall in profitability, and how the firms responded to it. The dividend rate of firms affiliated with affected trusts had been rising relative to other firms, but was cut sharply in 1908 and remained low in 1909 before recovering in 1910. In addition, the interest rates paid by firms affiliated with affected trusts relative to other firms increased substantially in 1907 and 1908, a sign that connected firms resorted to more expensive sources of credit. Since our measure of interest rates is an average rate calculated from total indebtedness, these changes most likely underestimate the increase in the marginal borrowing costs faced by these firms.

Figure 5 is a simple depiction of the trends in the dependent variables over time. Next, we turn to regressions to establish the magnitudes and statistical significance of the post-panic changes relative to the levels prior to the crisis, as well as to allow the effects to vary with the size of firms. Specifically, we estimate the following difference-in-difference regressions:

\footnotetext{
${ }^{56}$ The end of fiscal year varied across firms. To be consistent, we assigned accounting data to a given calendar year in our dataset if the fiscal year ended between July of that year and June of the following calendar year. Thus, the data represented in the points labeled 1907 in Figure 5 contain information from financial statements for fiscal years ended from July 1907 to June 1908, a blend of pre- and post-panic data.

${ }^{57}$ In the regressions that follow, controlling for such differential trends by including an indicator variable for firms affiliated with an affected trust in 1907 interacted with a time trend has no effect on the results obtained.
} 


$$
\begin{aligned}
\pi_{i t}=\alpha_{i}+\gamma_{t} & +\lambda_{1} \text { Affectedtrust }_{i} \times \text { postpanic }_{t}+ \\
+ & \lambda_{2} \text { Affectedtrust }_{i} \times \text { postpanic }_{t} \times \text { logassets } \text { lo }_{i}+\delta \boldsymbol{X}_{i t}+\varepsilon_{i t}
\end{aligned}
$$

where $\pi_{i t}$ is one of the measures of performance of interest for firm $i$ during year $t ; \alpha_{i}$ and $\gamma_{t}$ are firm and year fixed effects that control for time-invariant firm characteristics and for overall macroeconomic conditions; $\boldsymbol{X}_{i t}$ is a vector of time-varying firm characteristics, such as log assets; Affectedtrust $_{i} \times$ postpanic $_{t}$ is an indicator equal to one for all years for firms with a director of a trust that was differentially affected during the panic on its board multiplied by an indicator for the years 1907 and later; and Affectedtrust ${ }_{i} \times$ postpanic $_{t} \times$ logassets $6_{i}$ is that same indicator multiplied by the $\log$ value of the firm's assets in 1906. In this framework the differential effect on firm performance of having an affiliation with an affected trust in 1907 for the years during and after the financial crisis is $\left(\lambda_{1}+\lambda_{2} \operatorname{logassets}_{06}\right.$. $)$. If the effect is indeed concentrated among smaller firms, which may have suffered more from asymmetries of information, we would again expect $\lambda_{1}<0$, and $\lambda_{2}>0$.

Table 5 analyzes the effect of connections to affected trusts on firms’ profitability, using return on assets and return on equity. As in the rest of our analysis, the standard errors are clustered by firm in order to address potential problems of autocorrelation in residuals. Consistent with the notion that credit intermediation contracted in the wake of the panic, and that this contraction adversely impacted firms' ability to finance their operations and investments, all of the specifications indicate a negative effect on profitability that was greater for smaller firms. In columns (1) and (3), the estimated difference-in-differences for firms affiliated with affected trusts in the wake of the panic is about -0.2 and -0.8 percentage points for firms with the median level of log assets, and -0.5 and -1.3 percentage points for firms at the $25^{\text {th }}$ percentile of assets. ${ }^{58}$ The effects for the smaller firms are equivalent to a 13 and 15 percent decline relative to the mean values of ROA and ROE in 1906, respectively.

The summary statistics presented in Tables 2 and 3 suggest that the firms affiliated with the affected trusts had more extensive connections to financial institutions, were more levered and held

\footnotetext{
${ }^{58}$ For the 125 firms in the sample, the median value of log assets in 1906 is 18.025 , and the $25^{\text {th }}$ percentile is 17.302.
} 
lower cash balances prior to the crisis. Thus, omitted variables are a source of concern if firms with these characteristics performed differently in the years following the crisis, or evolved along a differential trend throughout the sample period. Therefore columns (2) and (4) of Table 5 include controls for firm characteristics that differed between connected and non-connected firms, as observed in 1906, interacted with a time trend. These include the number of trust companies represented on the firm's board, the number of seats held by the six major New York commercial banks on the firm's board, the firm's leverage ratio, and the firm's cash to assets ratio. ${ }^{59}$ In addition, the firms affiliated with the affected trust companies tended to operate in somewhat different industries than other firms. In order to address the possibility that these industry differences may have contributed to differences in performance following the panic, industry-specific trends are also added. The inclusion of all of these separate trends does not substantially alter the estimated effects. Table 6 uses similar specifications to study the effect of connections to affected trusts for dividend rates and interest rates. The estimated coefficients in columns (1) and (3) imply that firms with the median level of assets saw an increase in average interest rates of 0.28 percentage points and a decrease in dividend rates of -0.38 percentage points if they were affiliated with affected trusts relative to firms without those connections. For firms at the $25^{\text {th }}$ percentile of assets, these values become 0.39 and -0.65 percentage points, respectively, which is equivalent to 8.1 percent of the mean interest rate and 20 percent of the mean dividend rate in 1906. Columns (2) and (4) show that controlling for the same trends as in Table 5 does not alter the estimates substantially. Taken together, these results imply that firms with connections to the trust companies that came under acute pressure suffered a significant reduction in several measures of performance in the years following the panic, with particularly sizable effects for small firms.

\section{Robustness of the Effects on Firm Performance}

In this section, we address the most significant potential sources of concern regarding our results. In the Results Appendix, we explore the robustness of the results further by estimating

\footnotetext{
${ }^{59}$ Including controls for the number of items listed on the balance sheet or the number of insiders on the board does not alter the results. Thus, concerns about the quality of financial information across firms or the corporate governance of organizations do not seem to explain our findings.
} 
several alternative specifications of the regressions presented above.

One potential issue is that the firms that had no affiliation with an affected trust may not be an appropriate control group for those that did, since they were different by a number of observable characteristics. This concern does not seem very severe because the estimates in Table 3 indicate that there were no differential pre-panic trends along these (or other) characteristics, and the results in Tables 5 and 6 were robust to the inclusion of controls for differential trends. Still, to address this problem more thoroughly, we first eliminate from the control group those firms that had no affiliation with any trust company, which were likely to be the most 'different' from the firms with affiliations with affected trusts. Second, we use estimated propensity scores to restrict the sample to the common support in the propensity to have an affiliation with an affected trust, and also weight the observations by their inverse propensity scores. ${ }^{60}$ The results of these regressions, where the specifications chosen are the same as those with the full set of controls from Tables 5 and 6, are presented in Tables 7 and 8 . In general, the estimated effects are not substantially different. Statistical significance is lost for the dividend rate in column (2) of Table 8, but the magnitude of the estimated effect is substantially the same as that obtained from regressions that do not use the propensity score approach (Table 6, column (2)). Overall, these results indicate that control and treatment firms in our original sample were similar-that is, it is unlikely that a lack of common support creates bias in the results in Tables 5 and 6.

Another potential problem is that the smaller firms in our sample may have been subject to shocks unrelated to the trust companies with which they were affiliated—for example, an exogenous decline in the demand for their products during the crisis could have reduced their profitability. In order to address this issue, we look for additional evidence that the hypothesized mechanism of a contraction in financial intermediation worsened firm performance. If the loss of an affiliated provider of financial services forced some firms to seek alternative sources of finance, firms with

\footnotetext{
${ }^{60}$ Specifically, we estimate a firm-level probit regression of an indicator for an affiliation with an affected trust with 1906 measures of log assets, leverage, cash holdings, the number of seats held by major NY commercial banks, and industry indicators. We then restrict the sample to the common support in the propensity to have such an affiliation; that is, we eliminate firms without an affiliation with a propensity score below the minimum for the firms with an affiliation (and above the maximum for those with an affiliation). We weight the remaining observations by the inverse of the propensity score. This weighting strategy eliminates all significant differences in the chosen firm characteristics.
} 
collateral whose value was easily verified should have been best able to weather the panic. In the early twentieth century, the firms with the best collateral, and as a result those with the highest leverage ratios, were the railroads. With their extensive land holdings, track, and rolling stock, railroads had collateralizable assets whose value was relatively easy to establish. In contrast, the assets of many industrial firms were likely to include intangibles such as patents, and the physical capital of firms in some industries such as electrical supplies was much harder to value. We therefore test whether the railroads affiliated with affected trust companies suffered less than industrials in the years following the panic, relative to other firms.

Table 9 presents results from regressions that relate each of our outcome variables to separate interactions between the usual Affectedtrust $\times$ post-panic variable and indicator variables for railroads and for industrials. Consistent with the notion that firms with riskier collateral should have suffered more following the panic, we find that industrials performed worse according to every measure of performance, whereas the railroads were barely affected. ${ }^{61}$

A final and very important issue of concern, which is particularly difficult to address empirically, is that the results may be driven by selection on time-varying unobservable firm characteristics. If firms that were more sensitive to an economic downturn were matched to trust companies that were more adversely affected by the panic, then this selection process could account for the results that we attribute to the connections to affected financial intermediaries. Because these traits would become salient during the crisis, simply including firm and year fixed effects, as in our estimation framework, does not address this type of selection.

To test for the vulnerability of our affiliated firms directly, we use the experience of an earlier recession and financial panic in which trust companies did not face runs. In 1903 and 1904, the United States suffered a prolonged recession that included a financial panic during $1903 .{ }^{62}$ This so-called “Rich Man’s Panic” saw a sustained decline in securities prices, and led to a significant contraction in credit markets; "even the best railways and municipalities found it difficult to borrow on their accustomed terms” (Mitchell, 1913: p. 67). Although the recession was not as severe as the

\footnotetext{
${ }^{61}$ Within industrials, the largest effects are generally found among retailers and mining companies. The former had few fixed assets, whereas the latter had assets regarded as risky and difficult to value.

62 The NBER dates a peak in September 1902, and a trough in August 1904.
} 
one that followed the Panic of 1907, and did not result in widespread bank failures, it did produce substantial numbers of commercial failures and a significant contraction in demand (Romer, 1999). If the firms affiliated with affected trust companies in 1907 were fundamentally similar four years prior to that shock, in the sense that their vulnerability to shocks was roughly the same, and if the panic and recession that occurred can be considered reasonably similar to the panic of 1907, then the experience of firms that were affiliated with affected trusts in 1907 during the years 1903-04 should provide a test of whether they are indeed a differentially vulnerable group of firms.

We test this hypothesis using data from 1900-06. In particular, we investigate whether the firms that had affiliations with affected trusts in 1907 performed differentially worse in the years 1903 and 1904, and whether any such effects were heterogeneous and related to firm size. To perform this difference-in-difference analysis, we add the available accounting data from 1900 to 1902 in order to create a pre-period, and designate 1905 and 1906 a post-period. We estimate a regression of the same form as those above, focusing on the difference observed in the years 190304 relative to the pre- and post-period: ${ }^{63}$

$$
\begin{aligned}
\pi_{i t}=\alpha_{i}+\gamma_{t} & +\lambda_{1} \text { Affectedtrust }_{i} \times 1903 / 04_{t}+ \\
& +\lambda_{2} \text { Affectedtrust }_{i} \times 1903 / 04_{t} \times{\text { logassets } 04_{i}+\delta \boldsymbol{X}_{i t}+\varepsilon_{i t}}
\end{aligned}
$$

where now the differential effect of affiliation with an affected trust during the recession is equal to $\left(\lambda_{1}+\lambda_{2}\right.$ logassets $\left.04_{i}\right) .{ }^{64}$

The results, reported in Table 10, indicate that the firms affiliated with affected trusts in 1907 did not perform differentially worse in the 1903-04 recession. The estimates for ROA and ROE in columns (1) and (2) are much smaller in absolute value than those reported in Table 5 and are not statistically distinguishable from zero. In addition, the point estimates for $\lambda_{1}$ and $\lambda_{2}$ are

\footnotetext{
${ }^{63}$ We focus on the narrow window of the panic years relative to both the pre- and post-periods in order increase the number of firms for which we can estimate the effects. As the consequences of the panic were concentrated in 1903-04, this also makes it more likely to find an effect.

${ }^{64}$ Ideally we would like to use the value of assets in 1902, which would not reflect any effects of the recession. However, we observe the value of assets for only 38 firms in 1902, whereas we observe them for 90 firms in 1904. Results using the smaller sample with the 1902 log assets interaction are substantially unchanged.
} 
positive and negative, respectively - the opposite pattern found for the 1907 panic. Given that they are very imprecisely estimated, we are cautious about interpreting the precise magnitude of the estimated coefficients and comparing them with our earlier estimates. With this caveat in mind, the effect on ROA for a firm at the $25^{\text {th }}$ percentile in log assets is positive, and the effect on ROE is negative but only about 23 percent of the size of the effect from 1907. In column (3), the coefficients on the dividend rate become statistically significant but have the opposite signs than in the 1907 crisis; the effect for a small firm is an increase in the dividend rate of 0.07 percent. Finally, the interest rate on the debt of small firms actually fell by 0.13 percent (column 4).

The validity of this test hinges on whether or not the economic fundamentals of the firms affiliated with affected trusts in 1907 were substantially the same in 1903. Two potential sources of concern could be that some firms were subject to antitrust investigations, or were involved in mergers that may have weakened their balance sheets, after 1904. In the Results Appendix, we show that our estimated effects actually become stronger when all firms that were involved in federal antitrust cases or major mergers are excluded from the analysis (Appendix Table A3). Any interpretation of the results of this paper based on differential vulnerability of the firms affiliated with affected trusts in 1907 through channels other than the shocks to their connected financial intermediaries must confront the fact that these firms did not perform differentially worse in the 1903-04 panic and recession.

\section{Conclusion: Lessons of the Panic}

The Panic of 1907 was one of the most severe financial crises prior to the Great Depression, and shares many important features with the recent financial turmoil. This paper analyzes the disruption in financial intermediation that resulted from runs on trust companies — that era's 'shadow banks'—and finds a substantial and persistent impact on the non-financial corporations affiliated with the most severely affected trust companies. At the onset of the panic, the market value of these corporations declined to a much greater degree than they did other firms in the same industries. The performance of these firms, in terms of profitability, dividend rates, and borrowing costs, suffered 
for several years following the panic. That these runs were triggered by rumors about trust company directors unrelated to any major non-financial corporation helps to establish that the shock originated within the financial sector, and was transmitted to the trust companies' clients. This unique setup allows us to provide the first systematic evidence of the effect of a financial crisis on firm-level outcomes during the National Banking Era.

Several lessons can be inferred from our findings. First, the status of trust companies as 'shadow banks' is important to understanding the consequences of the crisis. In contrast to commercial banks — the more strictly regulated and better-established part of the financial system— trust companies lacked the institutions and mechanisms that helped minimize the impact of deposit runs at that time. Despite becoming a central part of New York’s financial markets, trust companies had no framework for coordination or mutual assistance, no option to suspend the convertibility of their deposits, and no access to the clearinghouse. Moreover, their recent rise to prominence and their innovative business model likely made depositors less trusting of their balance sheets, and more uncertain about whether trust companies could withstand a negative shock or a deposit run. In contrast, the commercial banks' suspension in 1907 minimized the spread of contagion among those institutions (Friedman and Schwartz, 1963), and their access to clearinghouse loans provided them with some liquidity. The total lending of New York's trust companies contracted by 37 percent during the crisis, but the city's commercial banks actually managed to increase lending slightly. Thus, the fact that the shock was centered on the 'shadow banks' likely contributed to the severity of the crisis, and to its propagation to other financial institutions and to the real economy.

A second point is that the rapid restoration of liquidity in the financial system was insufficient to prevent the decline in the performance of the non-financial firms affiliated with the most severely affected trust companies. One factor that may have contributed to the duration of the effects on the non-financial firms is that the severely affected trust companies did not recover for some time despite the rapid return of normalcy to financial markets. All New York trust companies experienced a contraction in their balance sheets during the crisis, and the total lending of these institutions did not return to its mid-1907 levels until April of 1909. Deposits in the strongest trust companies increased rapidly throughout the first half of 1908, whereas the most severely affected 
ones recovered much more slowly. Although they were all revealed to have been solvent during the crisis, and although all trust company depositors were eventually paid in full, the most severely affected institutions never regained their previous status as significant lenders. The panic was more than a scramble for liquidity; it had permanent effects on some trust companies, and significant prolonged consequences for many of their clients.

Finally, the differential effects of the contraction of intermediation on smaller firms and on industrials highlight the importance of asymmetries of information in understanding the impact of a panic. As in many countries of the world today with bank-centered financial systems, non-financial corporations in the early twentieth century United States affiliated themselves with financial intermediaries in a very public way, through board interlocks. These financial ties likely emerged to help resolve asymmetries of information between lenders and borrowers, and to 'certify' the corporations to investors or other lenders. When the panic struck it fundamentally changed the value of some of those affiliations. The prolonged impact on non-financial firms suggests that it took these corporations several years to establish new relationships with other financial institutions and to rebuild their reputations. Thus, the consequences of shocks to financial intermediation for the real economy may depend on the severity of asymmetric information problems in financial markets, and the institutions developed to address those problems. 


\section{Bibliography}

Adams, Renée B., Benjamin E. Hermalin, and Michael S. Weisbach. 2010. "The Role of Boards of Directors in Corporate Governance: A Conceptual Framework and Survey,” Journal of Economic Literature, 48(1): 58-107

Agrawal, Anup, Jaffe, Jeffrey F. and Jonathan M. Karpoff. 1999. “Management Turnover and Corporate Governance Changes Following the Revelation of Fraud," Journal of Law and Economics, 62(1), 309-42

Amiti, Mary, and David Weinstein. 2009. “Exports and Financial Shocks,” NBER Working Paper Series, number 1556.

Balke, Nathan, and Robert Gordon. 1989. "The Estimation of Prewar Gross National Product: Methodology and New Evidence,” Journal of Political Economy 97, 84-85.

Barnett, G. 1910. State Banks and Trust Companies since the Passage of the National Bank Act. Publications of the National Monetary Commission. Washington, DC: Government Printing Office.

Barton, Jan and Gregory Waymire. 2004. "Investor Protection Under Unregulated Financial Reporting,” Journal of Accounting and Economics, 38(1), 65-116.

Bayles, W. Harrison. 1919. "A History of the Origin and Development of Banks and Banking, and Banks and Banking in New York, Chapter 28,” in McMaster’s Commercial Cases, vol 22.

Bernanke, B. "Nonmonetary Effects of the Financial Crisis in the Propagation of the Great Depression.” The American Economic Review. Vol. 73, No. 3 (Jun., 1983), pp. 257-276.

Bernanke, Ben and Alan Blinder. 1988. "Credit, Money and Aggregate Demand,” American Economic Review, 78(2), 435-439.

Bernanke, Ben and Mark Gertler, 1989, “Agency Costs, Net Worth, and Business Fluctuations,” American Economic Review 79(1), 14-31.

Bernstein, Assaf, Hughson, Eric, and Weidenmier, Marc. 2010. "Identifying the Effects of a Lender of Last Resort on Financial Markets: Lessons from the Founding of the Fed.” Forthcoming, Journal of Financial Economics.

Berryman, William L. 1907. “The Modern Trust Company,” in Trust Companies, 4(2), p. 101.

Bordo, Michael, and Joseph G. Haubrich. 2010. "Credit Crises, Money and Contractions: An Historical View.” Journal of Monetary Economics.57, (2010): 1-18.

Bruner, R, and Carr S. 2007. The Panic of 1907: Lessons Learned from the Market's Perfect Storm. New York: John Wiley \& Sons, Inc.

Bullard James, Neely Christopher, and Wheelock, David. "Systemic Risk and the Financial Crisis: A Primer.” Federal Reserve Bank of St. Louis Review, Septempber/October 2009, 91(5, Part 1), pp.403-17.

Calomiris, Charles, and Gary Gorton. 2000. "The Origins of Banking Panics: Models, Facts, and Bank Regulation,” in U.S. Bank Deregulation in Historical Perspective. New York: Cambridge University Press. 
Calomiris, Charles, and Joseph R. Mason. 1993. "Consequences of Bank Distress During the Great Depression,” American Economic Review, 93(3), 937-47.

Campbell, John Y., Low, Andrew W., and A. Craig MacKinlay. 1997. The Econometrics of Financial Markets. Princeton: Princeton University Press.

Cantillo Simon, Miguel. 1998. “The Rise and Fall of Bank Control in the United States: 1890-1939,” American Economic Review, 88(5): 1077-93.

Carlson, Mark, Kris James Mitchener, and Gary Richardson. 2011. “Arresting Banking Panics: Federal Reserve Liquidity Provision and the Forgotten Panic of 1929,” Journal of Political Economy, 119(5): 889-924.

Carosso, Vincent. 1970. Investment Banking in America. Cambridge: Harvard University Press.

------. 1987. The Morgans: Private International Bankers, 1854-1913. Cambridge: Harvard University Press.

Carter, Susan B., et al. 2006. Historical Statistics of the United States, Millennial Edition. New York: Cambridge University Press.

Chandler, Alfred D. 1990. Scale and Scope: The Dynamics of Industrial Capitalism. Cambridge: Harvard University Press.

Chapman, E. R. 1910. Testimony in Allen Kingston Motor Car Co. v. Consolidated National Bank of New York. New York Supreme Court, Appellate Division-First Department. New York: Stillman Appellate Printing Co.

Chava, Sudheer, and Amiyatosh Purnandam. 2011. "The Effects of Banking Crisis on BankDependent Borrowers,” Journal of Financial Economics, 99, 116-35.

Conant, Charles A. 1904. Wall Street and the Country. New York: G.P. Putnam’s Sons.

DeAngelo, Harry, DeAngelo, Linda, and Rene Stulz. 2006. "Dividend Policy and the Earned/Contributed Capital Mix: A Test of the Life Cycle Theory,” Journal of Financial Economics, 81, 227-54.

DeLong, J. Bradford. 1991. “Did J.P. Morgan's Men Add Value? An Economist’s Perspective on Finance Capitalism," in Temin, ed. Inside the Business Enterprise: Historical Perspectiveso n the Use of Information. Chicago: University of Chicago Press.

Diamond, Douglas W. 1984. "Financial intermediation and delegated monitoring," Review of Economic Studies 51, 393-414.

Diamond Douglas W, and Philip H Dybvig. 1983. "Bank runs, deposit insurance, and liquidity,” Journal of Political Economy 91 (3): 401-419

Fernando, Chitru S., May, Anthody D., and William L. Meggison. 2012. "The Value of Investment Banking Relationships: Evidence from the Collapse of Lehman Brothers,” Journal of Finance, 67(1), pp. 235-270.

Fich, Eliezer and Anil Shivdasani. 2007. "Financial Fraud, Director Reputation, and Shareholder Wealth,” Journal of Financial Economics, 86(2), 306-336. 
Friedman, Milton, and Anna J. Schwartz. 1963. A Monetary History of the United States. Princeton: Princeton University Press / NBER.

Gorton, Gary. 1985. “Clearing Houses and the Origin of Central Banking in the U.S.,” Journal of Economic History, 45(2), 277-83.

Gorton, Gary. 1988. “Banking Panics and Business Cycles,” Oxford Economic Papers, 40, 751-81.

Gorton, Gary, and Andrew Metrick. 2010. "Regulating the Shadow Banking System.” Brookings Papers on Economic Activity, Fall.

Guiso, Luigi, Paola Sapienza and Luigi Zingales. 2008. "Trusting the Stock Market,” The Journal of Finance 63(6): 2557-2600.

Guner, A. Burak, Ulrike Malmendier, and Geoffrey Tate. 2008. "Financial Expertise of Directors," Journal of Financial Economics, 88 (2), 323-354.

Hanes, Christopher L., and Paul Rhode. 2011. "Harvests and Financial Crises in Gold-Standard America.” Working paper, Binghamton University.

Hanna, John. 1931. “The Knickerbocker Trust Company: A Study in Receivership.” Temple Law Quarterly, 5(3), pp. 319-48.

Hansen, Bradley. 2011. "Sometimes Bad Things Happen to Good Trust Companies: A Reexamination of the Trust Company Panic of 1907.” Draft, University of Mary Washington.

Holmstrom, Bengt and Jean Tirole, 1997, "Financial Intermediation, loanable funds, and the real sector,” Quarterly Journal of Economics 112, 665-691.

James, John, McAndrews, James, and David F. Weiman. 2011. "Suspensions of Payments under the National Banking Act.” Working paper, University of Virginia.

Judd, Orrin R. 1907. “The New York Trust Company Reserve Law.” Trust Companies, 7(1), p. 2.

Kayshap, Anil, Lamont, Owen, and Jeremy C. Stein. 1994. "Credit Conditions and the Cyclical Behavior of Inventories,” Quarterly Journal of Economics, 109(3), pg 565-92.

Khwaja, Asim and Atif Mian. 2008. "Tracing the Impact of Bank Liquidity Shocks: Evidence from an Emerging Market,” American Economic Review, 98(4), pp 1413-42.

Kilburn, Frederic D. 1904. “An Opinion Concerning Trust Company Reserves,” Trust Companies, 1(1), pp. 27-29.

Kroszner, Randall S., and Philip E. Strahan. 2001. "Bankers on Boards: Monitoring, Conflicts of Interest, and Lender Liability,” Journal of Financial Economics, 62 (3), 415-52.

Kupiec, Paul H., and Carlos D. Ramirez. 2012. "Bank Failures and the Cost of Systemic Risk: Evidence from 1900 to 1930,” Working Paper, FDIC and George Mason.

Lamoreaux, Naomi. 1985. The Great Merger Movement in American Business, 1895-1904. New York: Cambridge University Press.

Lefevre, Edwin. 1908. "The Game Got Them: How the Great Wall Street Gambling Syndicate Fell Into its Own Trap,” Everybody’s Magazine, 18(1), pp. 3-14. 
McCartney, S., and A.J. Arnold. 2002. "Financial Reporting in the Context of Crisis: Reconsidering the Impact of the 'Mania' on Early Railway Accounting," European Accounting Review, 11(2), 401-17.

McNelis, Sarah. 1968. Copper King At War: The Biography of F. Augustus Heinze. University of Montana Press.

Miron, Jeffrey A. 1986. "The Nominal Interest Rate, Seasonality, and the Founding of the Fed.” American Economic Review, 76 (1).

Mishkin, Frederic S. 1991. “Asymmetric Information and Financial Crises: A Historical Perspective.” In R. Glenn Hubbard, ed. Financial Markets and Financial Crises. Chicago: University of Chicago / NBER.

Mitchell, Wesley C. 1913. Business Cycles. Berkeley: University of California Press.

Mladjan, Mrdjan. 2012. “Accelerating into the Abyss: Financial Dependence and the Great Depression.” Working Paper, Universitat Pompeu Fabra.

Moen, J. and Tallman, E. 1990. “Lessons of the Panic of 1907," Federal Reserve Bank of Atlanta Economic Review, May/June.

------ and ------. 1992. “The Bank Panic of 1907: The Role of Trust Companies.” The Journal of Economic History, 52(3), pp. 611-630

------ and ------. 2000. “Clearinghouse Membership and Deposit Contraction During the Panic of 1907,” Journal of Economic History, 60(1), pp.145-163.

Neal, Larry. 1971. “Trust Companies and Financial Innovation, 1897-1914,” Business History Review, 45(1), pp. 35-51.

Odell, K. and Weidenmier, M. 2004. "Real Shock, Monetary Aftershock: The 1906 San Francisco Earthquake and the Panic of 1907.” Journal of Economic History, 64 (4).

Pak, Susie, and Daniel S. Halgin. 2010. "The Social Network of J.P. Morgan \& Co., 1895-1940: Interlocking Directorates, Social Clubs, and Syndicates.” Working Paper, St. John’s Univeristy.

Paravisini, Daniel, Veronica Rappoport, Philipp Schnabl and Daniel Wolfenzon, 2011. "Dissecting the Effect of Credit Supply on Trade: Evidence from Matched Credit-Export Data,” Working Paper, Columbia University.

Peek, Joe, and Eric S. Rosengren. 2000. "Collateral Damage: Effects of the Japanese Bank Crisis on Real Activity in the United States,” American Economic Review, 90(1): 30-45.

Ramirez, Carlos D. 1995. “Did J.P. Morgan’s Men Add Liquidity? Corporate Investment, Cash Flow, and Financial Structure at the Turn of the Twentieth Century," Journal of Finance, 50(2): $661-78$

Redlich, F. 1951. The Molding of American Banking: Men and Ideas. New York: Hafner Publishing Co.

Richardson, Gary and William Troost. 2009. "Monetary Intervention Mitigated Banking Panics during the Great Depression: Quasi-Experimental Evidence from a Federal Reserve District Border, 1929-1933,” Journal of Political Economy, 117(6): 1031-73 
Rodgers, Mary Tone, and Berry K. Wilson. 2011. "Systemic Risk, Missing Gold Flows and the Panic of 1907.” Quarterly Journal of Austrian Economics, 14(2), pp. 158-87.

Romer, Christina. 1999. “Changes in Business Cycles: Evidence and Explanations,” Journal of Economic Perspectives, 13(3), pp. 23-44.

Sapienza, Paola, and Luigi Zingales. 2012. “A Trust Crisis,” International Review of Finance, 12(2), 123-131.

Schnabl, Philip. 2011. "The International Transmission of Bank Liquidity Shocks: Evidence from an Emerging Market.” Journal of Finance, forthcoming.

Senate Committee on Banking and Currency. 1912. Hearings on a Bill to Provide For the Establishment of Federal Reserve Banks. Washington: Government Printing Office.

Simon, M. 1989. "The Rise and Fall of Bank Control in the United States: 1890-1939.” American Economic Review, Vol. 88 (5), pp. 1077-1093.

Sinclair, Upton. 1908. The Moneychangers. New York: B. W. Dodge \& Co.

Sivakumar, K.N., and Gregory Waymire. 1993. "The Information Content of Earnings in a Discretionary Reporting Environment: Evidence from NYSE Industrials, 1905-10,” Journal of Accounting Research, 31(1), 62-91.

Smith, James G. 1928. The Development of Trust Companies in the United States. New York: Henry Holt \& Co.

Sprague, O.M.W. 1910. A History of Crises Under the National Banking System. Publications of the National Monetary Commission. Washington, DC: Government Printing Office.

Stein, Jeremy. 1998. “An Adverse Selection Model of Bank Asset and Liability Management with Implications for the Transmission of Monetary Policy.” RAND Journal of Economics 29(3), 466-486.

Strouse, Jean. 1999. Morgan: American Financier. New York: Random House.

Weinstein, David E., and Yishay Yafeh. 1998. "On the Costs of a Bank-Centered Financial System: Evidence from the Changing Main Bank Relations in Japan,” Journal of Finance, 53(2), 63572.

White, Eugene. 1983. The Regulation and Reform of the American Banking System, 1900-1929. Princeton: Princeton University Press.

Wicker, Elmus. 2000. Banking Panics of the Gilded Age. Cambridge, U.K.: Cambridge University Press, 2000.

-----. 2005. The Great Debate on Banking Reform: Nelson Aldrich and the Origins of the Fed. Columbus, Ohio: Ohio State University Press.

Williams, Clark. 1909. Annual Report of the Superintendant of Banks. New York Senate Documents, number 6.

Ziebarth, Nicholas. 2012. "Misallocation and Productivity During the Great Depression.” Working Paper, Northwestern University. 


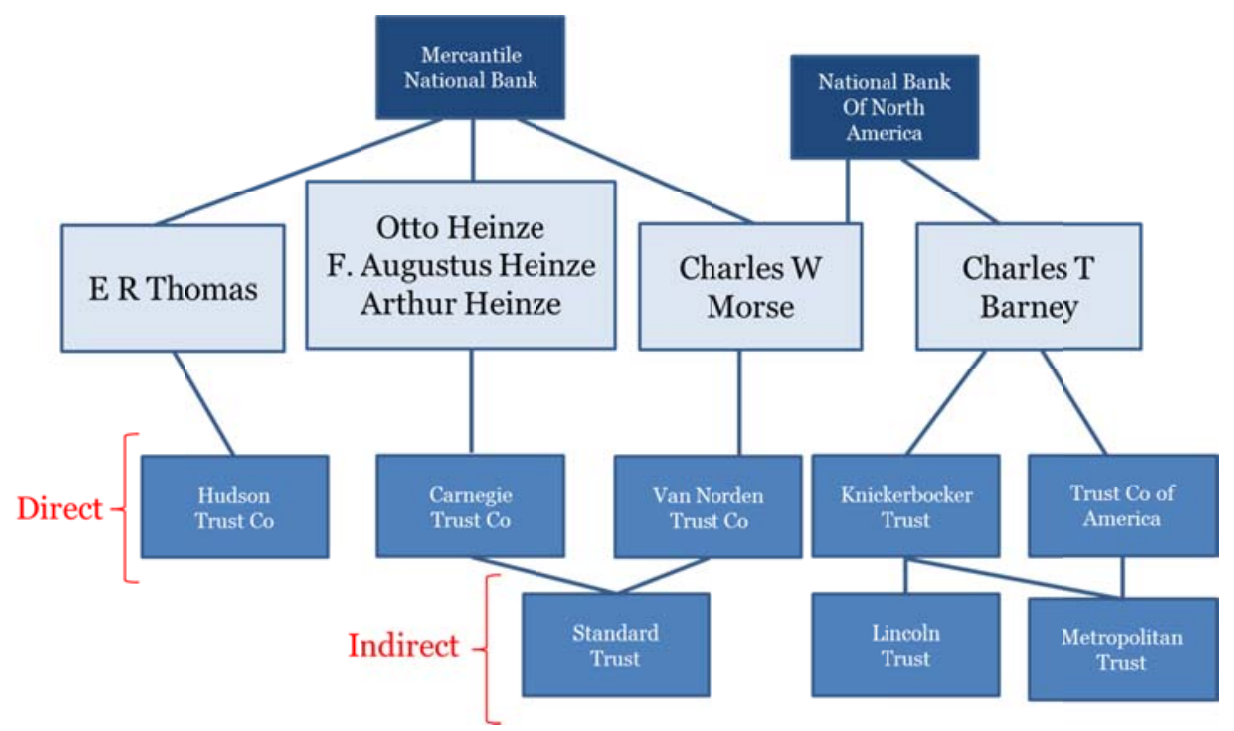

Figure 1: Connections between speculators and trust companies

Lines connecting individuals and institutions (or institutions to other institutions) indicate where directorships are held. The institutions at the top of the figure are the national banks that connect the speculators to one another and to Barney. Morse, Thomas and the Heinzes also controlled several other banks (not shown). The group of trust companies denoted as having an indirect connection to the speculation was defined as those with at least two directors in common with those that had a direct connection.

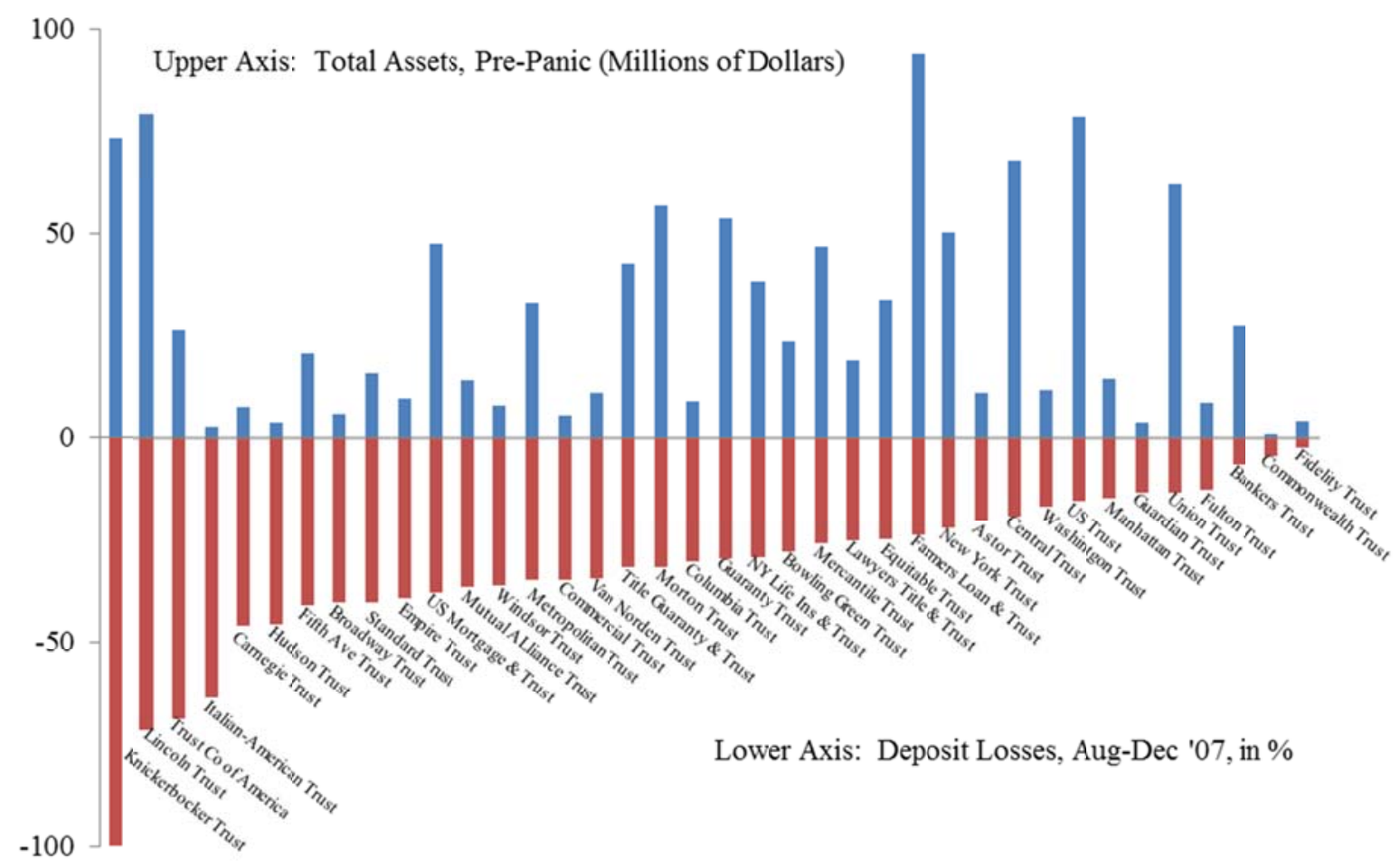

Figure 2: Assets and deposit losses at New York City trust companies

Upper axis: total assets, June 1907, in millions. Lower axis: percentage change in deposits between August 22, 1907 and December 19, 1907, in percent. 


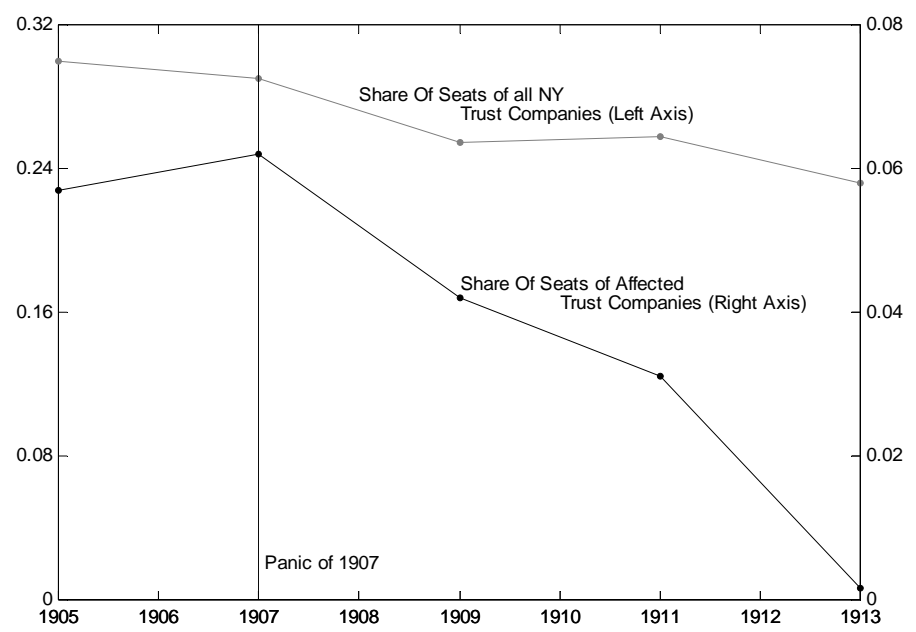

Figure 3: Board seats held by trust company directors, 1905-1913

Percent of all board seats of NYSE-listed railroads and industrials held by directors of New York City trust companies, and by directors of the differentially affected trust companies, defined as those among the top $25 \%$ in deposit losses during the Panic of 1907.

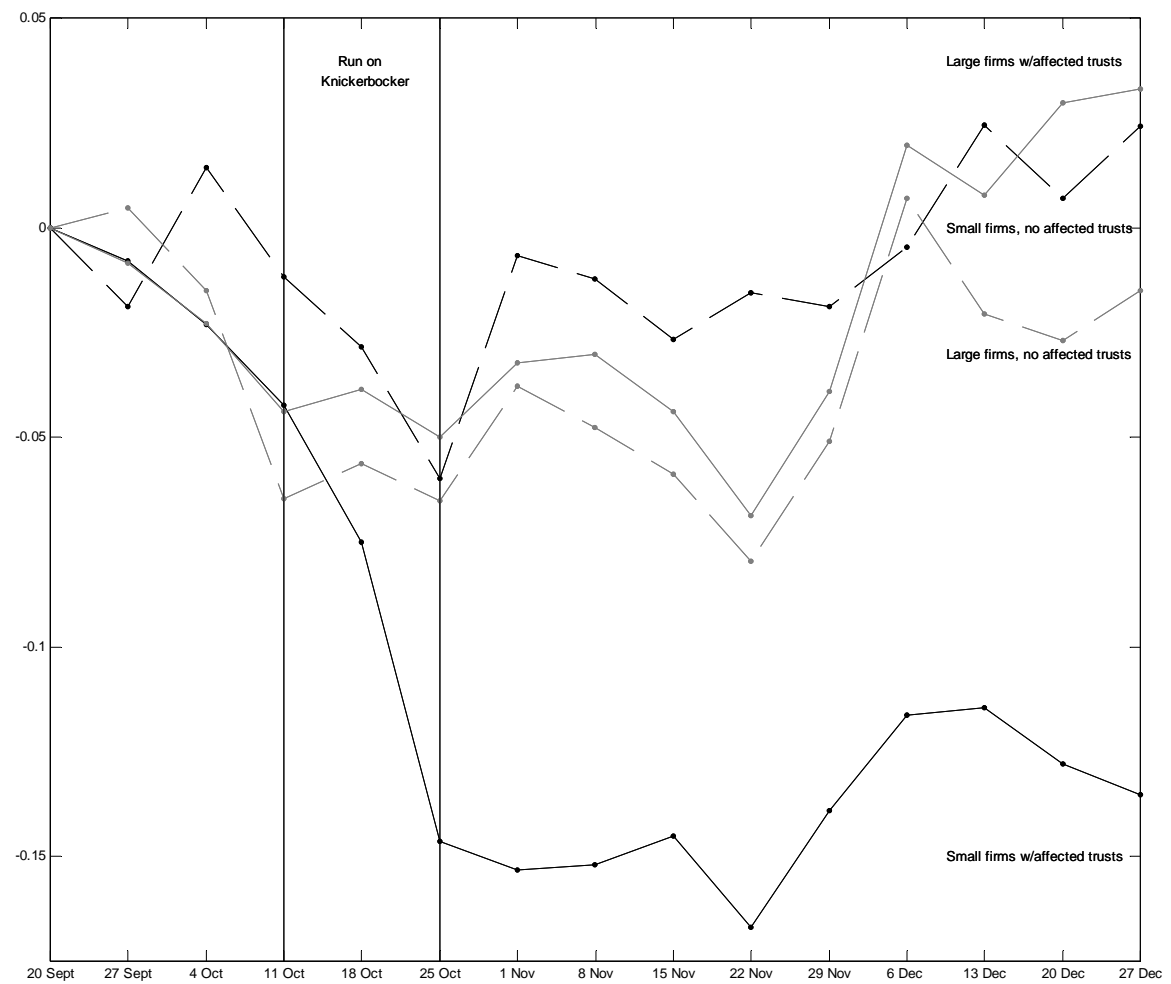

Figure 4: Stock market reaction, by affiliation and by size

The lines in the figure present the cumulative, industry-adjusted weekly returns from 20 September through 27 December, 1907. Small firms are defined as those with below-median assets. The run on Knickerbocker began silently around 16 October, and ended with the closure of the firm on 22 October. 

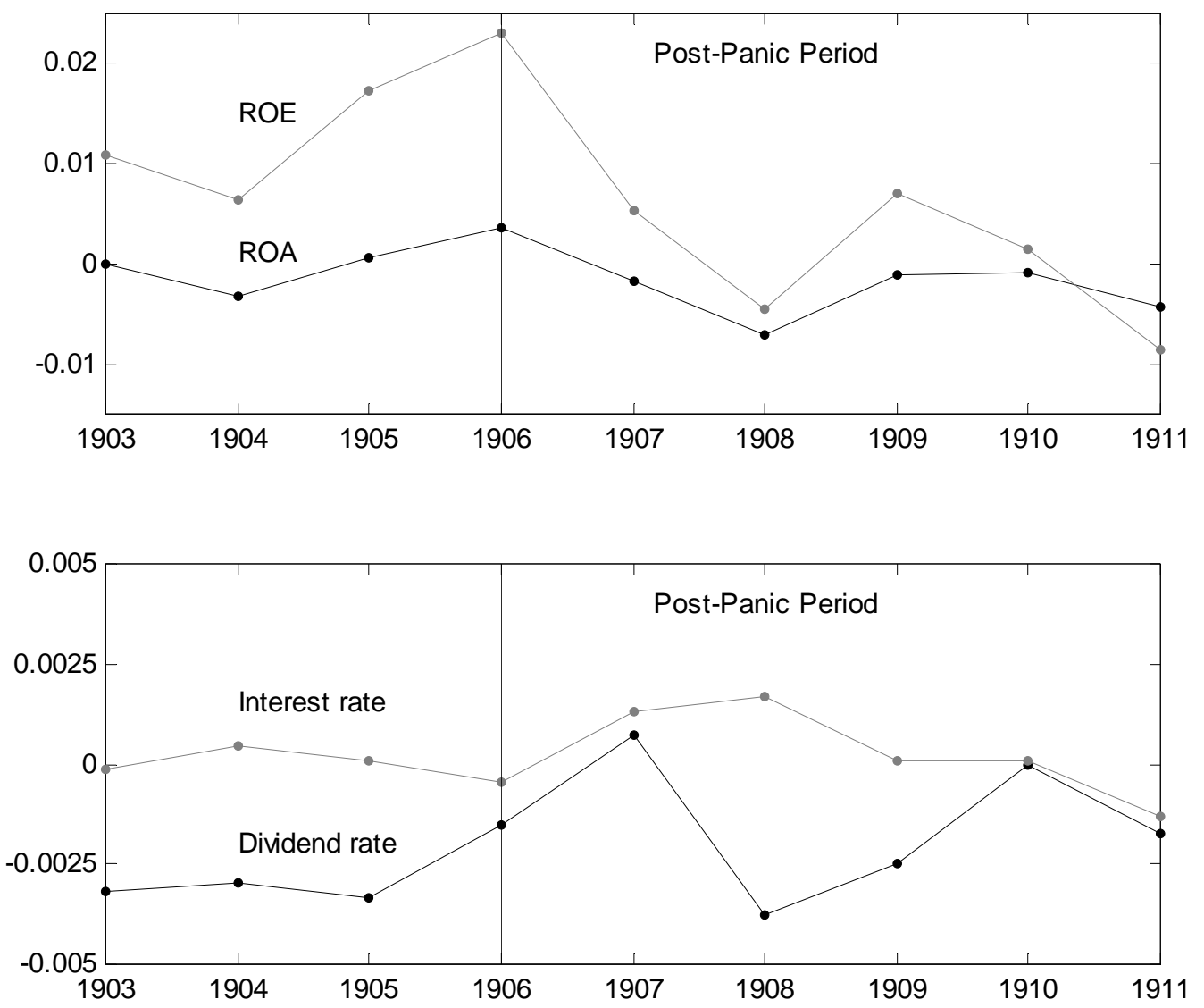

Figure 5: Annual estimated differences between firms with and without affected trusts Each line plots the annual difference between firms with and without affected trusts on their board in 1907, as estimated in a regression that controls for firm fixed effects and firm assets. All reported differences are relative to 1912. The units on the vertical axis represent the levels of the variables; a value of 0.01 implies a difference of 1 percent between firms with and without affiliations with affected trust companies. For each year, each variable is constructed using the annual financial information for all firms with a fiscal year ending between July of that year and June of the following year. 
Table 1

Percent Change in Deposits, August-December 1907, New York City Trust Companies

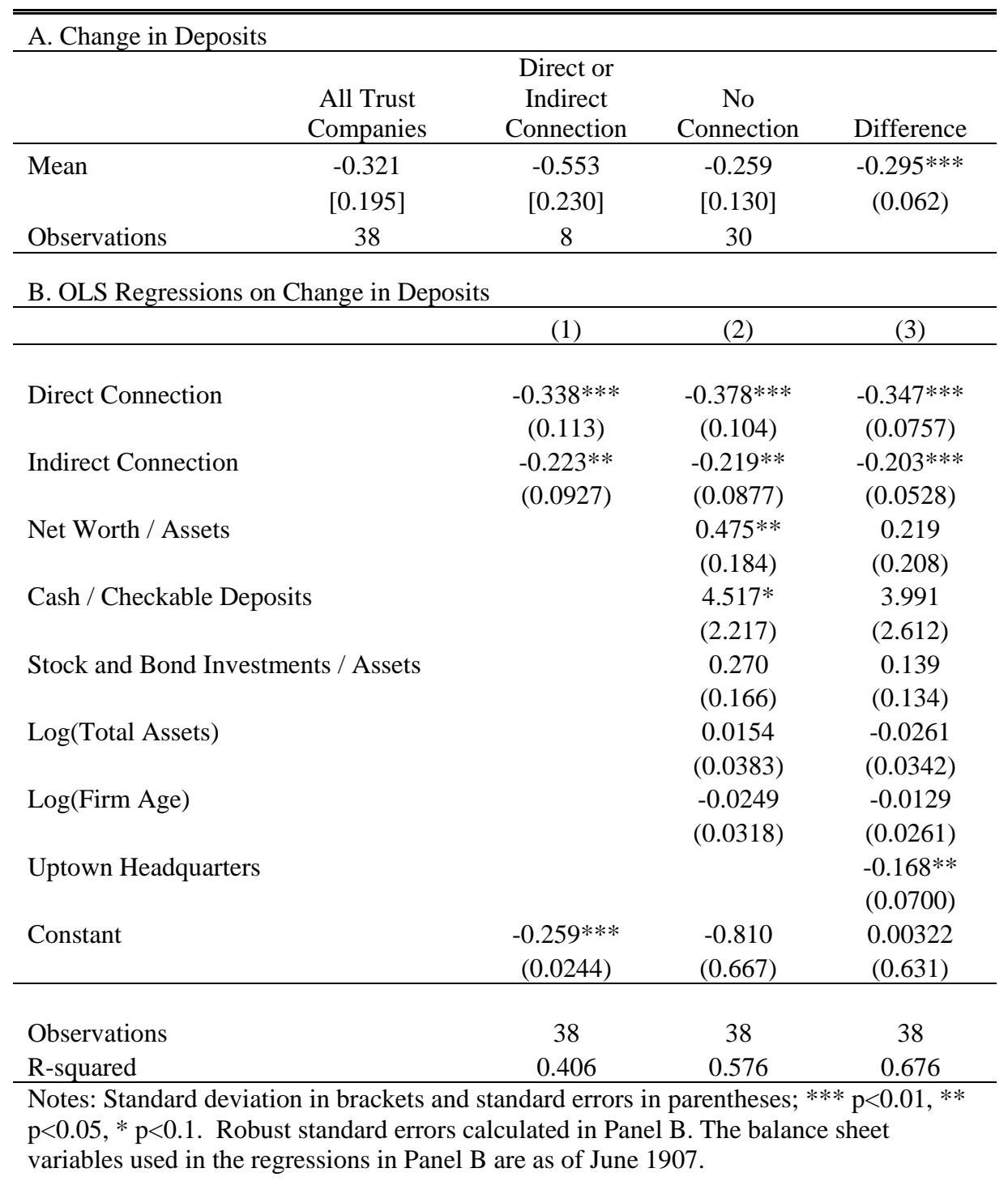


Table 2

Summary Statistics, Firm characteristics

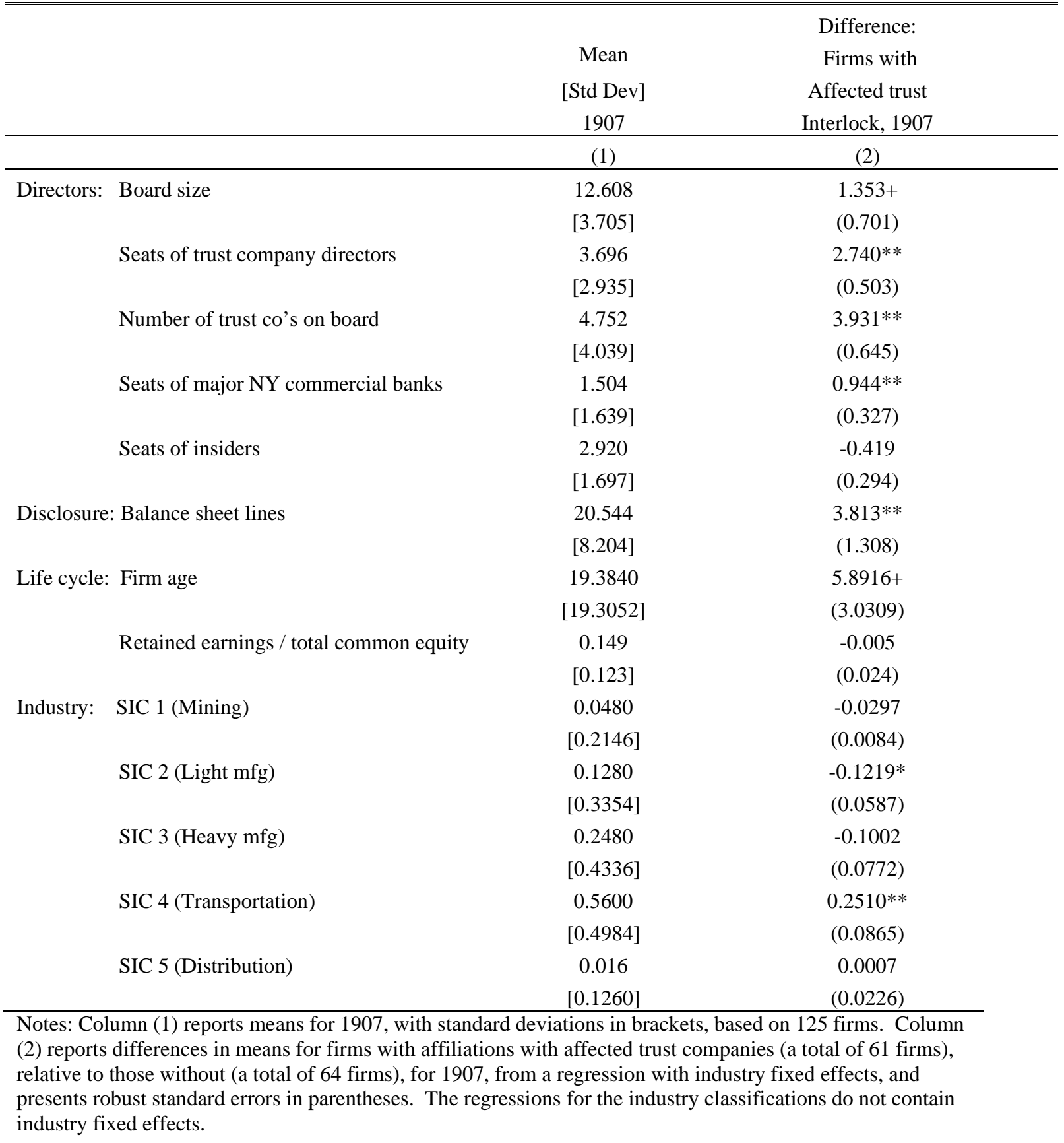


Table 3

Summary Statistics, Financial Variables

\begin{tabular}{lccc}
\hline \hline & Mean & Difference: & Differential trend: \\
& Firms with & Firms with affected \\
& Trust interlock, \\
& 1906 & Affected trust & $1903-1906$ \\
\hline Interlock, 1906 & $(2)$ & $(3)$ \\
\hline Log(Assets) & $(1)$ & $0.4726^{*}$ & 0.0060 \\
Cash/Assets & 18.1021 & $(0.1991)$ & $(0.0133)$ \\
& {$[1.1412]$} & $-0.0095+$ & -0.0021 \\
Leverage Ratio & 0.0282 & $(0.0048)$ & $(0.0025)$ \\
& {$[0.0306]$} & $0.0753^{* *}$ & 0.0091 \\
ROA & 0.2935 & $(0.0253)$ & $(0.0060)$ \\
& {$[0.2039]$} & -0.0047 & -0.0006 \\
ROE & 0.0383 & $(0.0054)$ & $(0.0014)$ \\
& {$[0.0342]$} & 0.0100 & 0.0023 \\
Dividend Rate & 0.0835 & $(0.0108)$ & $(0.0031)$ \\
& {$[0.0556]$} & 0.0028 & -0.0002 \\
Interest Rate & 0.0320 & $(0.0084)$ & $(0.0019)$ \\
& {$[0.0403]$} & -0.0020 & -0.0013 \\
& 0.0481 & $(0.0022)$ & $(0.0009)$ \\
\hline
\end{tabular}

Notes: For a given year, the table uses the annual financial information for all firms with a fiscal year ending between July of that year and June of the following year. Column (1) reports means for 1906, with the standard deviations in brackets. Column (2) reports differences in means for firms with affiliations with affected trust companies (a total of 61 firms), relative to those without (a total of 64 firms), for 1906, from a regression with industry fixed effects, and presents robust standard errors in parentheses. Column (3) presents the differential trends estimated from regressions with year fixed effects and firm fixed effects for 1903-1906, and presents standard errors adjusted for clustering by firm. **, * and + denote significance at $1 \%, 5 \%$ and $10 \%$, respectively. 


\section{Table 4}

\section{Stock Returns at the Onset of the Panic}

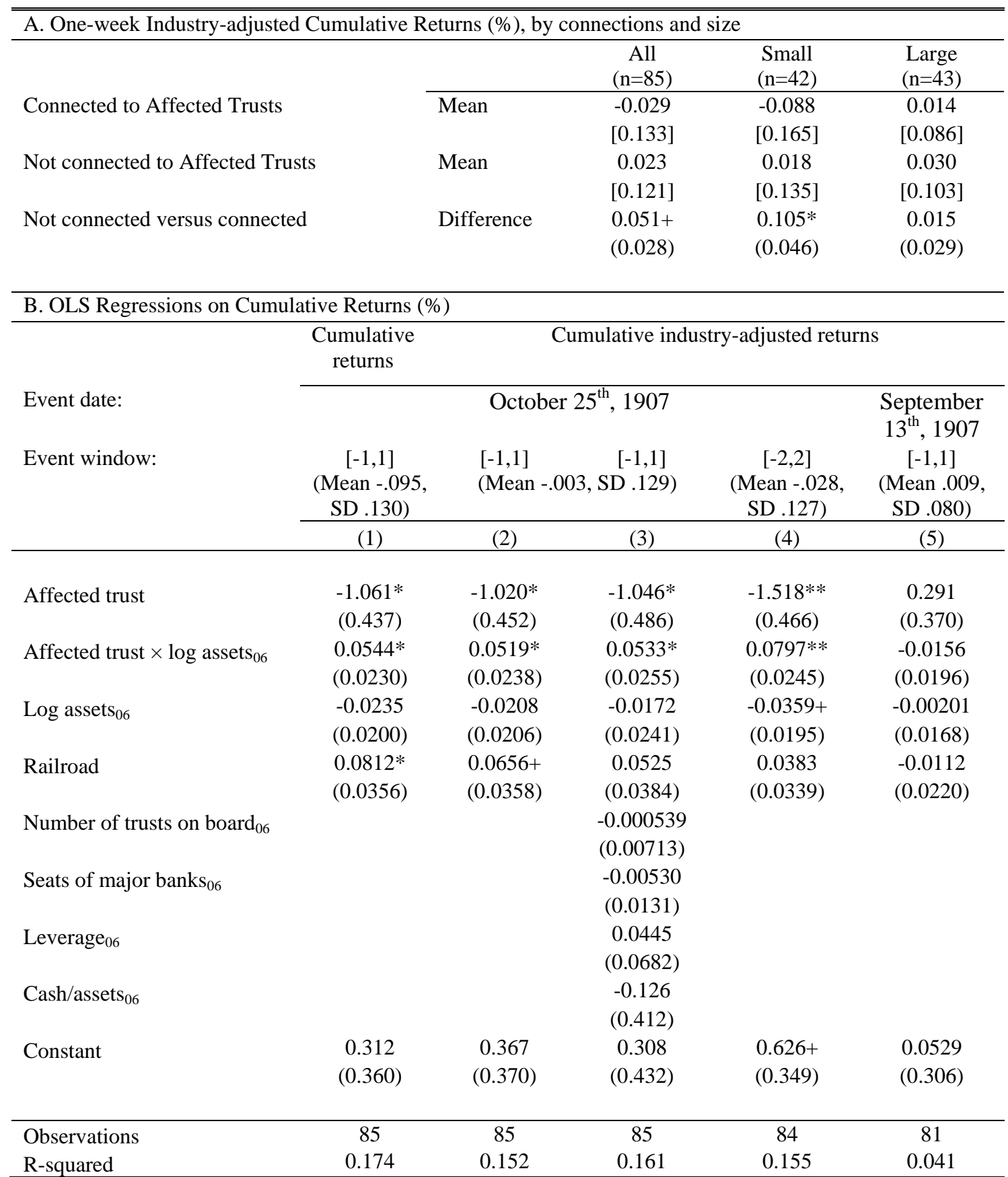

Notes: Standard deviation in brackets and robust standard errors in parentheses. **, *, and + indicate significance at the 1, 5 and 10 percent level, respectively. Returns adjusted by value-weighted industry returns on each date. Returns are cumulated over a window of one week around October $25^{\text {th }}, 1907$ in Panel A and columns (1)-(3) in Panel B. Column (4) cumulates returns over two weeks around this date, while column (5) cumulates returns over 1 week around September $13^{\text {th }}$, 1907. Small (large) firms are defined as below (above) median log assets in 1906 for the 78 firms with non-missing cumulative returns. The log assets interaction in the second row of Panel B uses the value of assets in 1906. In column (3) the added regressors are observed in 1907, in the case of the board variables, or 1906, in the case of the accounting variables. 
Table 5

Effects of Connections to Affected Trusts on Firm Profitability

\begin{tabular}{|c|c|c|c|c|}
\hline & \multicolumn{2}{|c|}{$\begin{array}{c}\text { ROA: } \\
\text { (Mean .033, SD .033) }\end{array}$} & \multicolumn{2}{|c|}{$\begin{array}{c}\text { ROE: } \\
\text { (Mean .070, SD .053) }\end{array}$} \\
\hline & $(1)$ & $(2)$ & (3) & $(4)$ \\
\hline Affected trust $\times$ post-panic & $\begin{array}{c}-0.0737 * * \\
(0.0255)\end{array}$ & $\begin{array}{c}-0.0654 * * \\
(0.0248)\end{array}$ & $\begin{array}{l}-0.121 * \\
(0.0533)\end{array}$ & $\begin{array}{l}-0.122 * \\
(0.0561)\end{array}$ \\
\hline Affected trust $\times$ post-panic $\times \log$ assets $_{06}$ & $\begin{array}{l}0.00398 * * \\
(0.00135)\end{array}$ & $\begin{array}{c}0.00350 * * \\
(0.00133)\end{array}$ & $\begin{array}{l}0.00625^{*} \\
(0.00285)\end{array}$ & $\begin{array}{l}0.00628 * \\
(0.00302)\end{array}$ \\
\hline Number of trusts on board $\mathrm{b6}_{06} \times$ time trend & & $\begin{array}{l}-0.000051 \\
(0.000042)\end{array}$ & & $\begin{array}{l}-0.000026 \\
(0.000094)\end{array}$ \\
\hline Seats of major banks ${ }_{06} \times$ time trend & & $\begin{array}{l}-0.000012 \\
(0.000176)\end{array}$ & & $\begin{array}{l}-0.000226 \\
(0.000336)\end{array}$ \\
\hline Leverage $_{06} \times$ time trend & & $\begin{array}{l}0.00293+ \\
(0.00150)\end{array}$ & & $\begin{array}{c}0.00247 \\
(0.00331)\end{array}$ \\
\hline Cash/assets $_{06} \times$ time trend & & $\begin{array}{l}-0.00705 \\
(0.00575)\end{array}$ & & $\begin{array}{l}-0.0196 \\
(0.0119)\end{array}$ \\
\hline Log assets & $\begin{array}{l}-0.00716 \\
(0.00595)\end{array}$ & $\begin{array}{l}-0.00303 \\
(0.00597)\end{array}$ & $\begin{array}{c}0.0229 \\
(0.0140)\end{array}$ & $\begin{array}{l}0.0302+ \\
(0.0158)\end{array}$ \\
\hline Constant & $\begin{array}{c}0.164 \\
(0.109)\end{array}$ & $\begin{array}{l}0.0692 \\
(0.109)\end{array}$ & $\begin{array}{l}-0.350 \\
(0.258)\end{array}$ & $\begin{array}{l}-0.496+ \\
(0.290)\end{array}$ \\
\hline Observations & 1,063 & 1,063 & 1,047 & 1,047 \\
\hline R-squared & 0.859 & 0.871 & 0.795 & 0.801 \\
\hline Firm FE & YES & YES & YES & YES \\
\hline Year FE & YES & YES & YES & YES \\
\hline Industry-specific trends & $\mathrm{NO}$ & YES & NO & YES \\
\hline $\begin{array}{l}\text { Notes: Standard errors adjusted for clusteri } \\
1,5 \text { and } 10 \text { percent level, respectively. Th } \\
\text { 1906. In columns (2) and (4), the added re } \\
\text { 1906, in the case of the accounting variabl } \\
\text { the annual financial information for all firn } \\
\text { the following year. }\end{array}$ & $\begin{array}{l}\text { rm in paren } \\
\text { sets interact } \\
\text { are observt } \\
\text { nteracted w } \\
\text { a fiscal year }\end{array}$ & $\begin{array}{l}\text { eses. } * *, *, \\
\text { in the seco } \\
\text { in } 1907 \text {, in } t \\
\text { a time trenc } \\
\text { ading betwe }\end{array}$ & $\begin{array}{l}\text { ndicate sig } \\
\text { uses the v } \\
\text { e of the bo } \\
\text { given yea } \\
\text { of that ye }\end{array}$ & $\begin{array}{l}\text { cance at the } \\
\text { of assets in } \\
\text { variables, or } \\
\text { e table uses } \\
\text { nd June of }\end{array}$ \\
\hline
\end{tabular}




\section{Table 6}

\section{Effects of Connections to Affected Trusts on Dividend and Interest Rates}

\begin{tabular}{|c|c|c|c|c|}
\hline & \multicolumn{2}{|c|}{$\begin{array}{c}\text { Dividend Rate: } \\
\text { (Mean .033, SD .043) }\end{array}$} & \multicolumn{2}{|c|}{$\begin{array}{c}\text { Interest Rate } \\
\text { (Mean .047, SD .010) }\end{array}$} \\
\hline & $(1)$ & $(2)$ & (3) & $(4)$ \\
\hline Affected trust $\times$ post-panic & $\begin{array}{c}-0.0703 * \\
(0.0352)\end{array}$ & $\begin{array}{c}-0.0594+ \\
(0.0335)\end{array}$ & $\begin{array}{c}0.0309 * \\
(0.0143)\end{array}$ & $\begin{array}{c}0.0381^{*} \\
(0.0176)\end{array}$ \\
\hline Affected trust $\times$ post-panic $\times \log$ assets $_{06}$ & $\begin{array}{c}0.00369+ \\
(0.00191)\end{array}$ & $\begin{array}{l}0.00323+ \\
(0.00183)\end{array}$ & $\begin{array}{l}-0.00156^{*} \\
(0.000776)\end{array}$ & $\begin{array}{c}-0.00197 * \\
(0.000962)\end{array}$ \\
\hline Number of trusts on board ${ }_{06} \times$ time trend & & $\begin{array}{l}-0.000045 \\
(0.00007)\end{array}$ & & $\begin{array}{l}-0.000006 \\
(0.000032)\end{array}$ \\
\hline Seats of major banks ${ }_{06} \times$ time trend & & $\begin{array}{c}0.000105 \\
(0.000299)\end{array}$ & & $\begin{array}{l}-0.000006 \\
(0.000121)\end{array}$ \\
\hline Leverage $_{06} \times$ time trend & & $\begin{array}{c}-0.00301 \\
(0.00268)\end{array}$ & & $\begin{array}{c}0.00186 \\
(0.00122)\end{array}$ \\
\hline Cash/assets ${ }_{06} \times$ time trend & & $\begin{array}{c}0.0122 \\
(0.0177)\end{array}$ & & $\begin{array}{c}0.0123 \\
(0.00801)\end{array}$ \\
\hline Log assets & $\begin{array}{c}0.00728 \\
(0.00940)\end{array}$ & $\begin{array}{c}0.00571 \\
(0.0106)\end{array}$ & $\begin{array}{l}-0.00224 \\
(0.00440)\end{array}$ & $\begin{array}{l}-0.00696 \\
(0.00454)\end{array}$ \\
\hline Constant & $\begin{array}{c}-0.0939 \\
(0.172)\end{array}$ & $\begin{array}{l}-0.0884 \\
(0.196)\end{array}$ & $\begin{array}{c}0.0867 \\
(0.0814)\end{array}$ & $\begin{array}{c}0.172 * \\
(0.0828)\end{array}$ \\
\hline Observations & 1,066 & 1,066 & 745 & 745 \\
\hline R-squared & 0.881 & 0.888 & 0.679 & 0.694 \\
\hline Firm FE & YES & YES & YES & YES \\
\hline Year FE & YES & YES & YES & YES \\
\hline Industry-specific trends & NO & YES & NO & YES \\
\hline $\begin{array}{l}\text { Notes: Standard errors adjusted for clusteri } \\
1,5 \text { and } 10 \text { percent level, respectively. The } \\
\text { 1906. In columns (2) and (4), the added re } \\
\text { 1906, in the case of the accounting variable } \\
\text { the annual financial information for all firn } \\
\text { the following year. }\end{array}$ & $\begin{array}{l}\text { rm in paren } \\
\text { ets interact } \\
\text { are observ } \\
\text { nteracted w } \\
\text { fiscal yea }\end{array}$ & $\begin{array}{l}\text { eses. **, *, } \\
\text { in the seco } \\
\text { in 1907, in } \\
\text { a time tren } \\
\text { ading betwe }\end{array}$ & $\begin{array}{l}\text { indicate sig } \\
\text { w uses the va } \\
\text { se of the boa } \\
\text { a given yea } \\
\text { ly of that yea }\end{array}$ & $\begin{array}{l}\text { icance at the } \\
\text { e of assets ir } \\
\text { variables, o } \\
\text { he table uses } \\
\text { nd June of }\end{array}$ \\
\hline
\end{tabular}


Table 7

Robustness checks on Firm Profitability

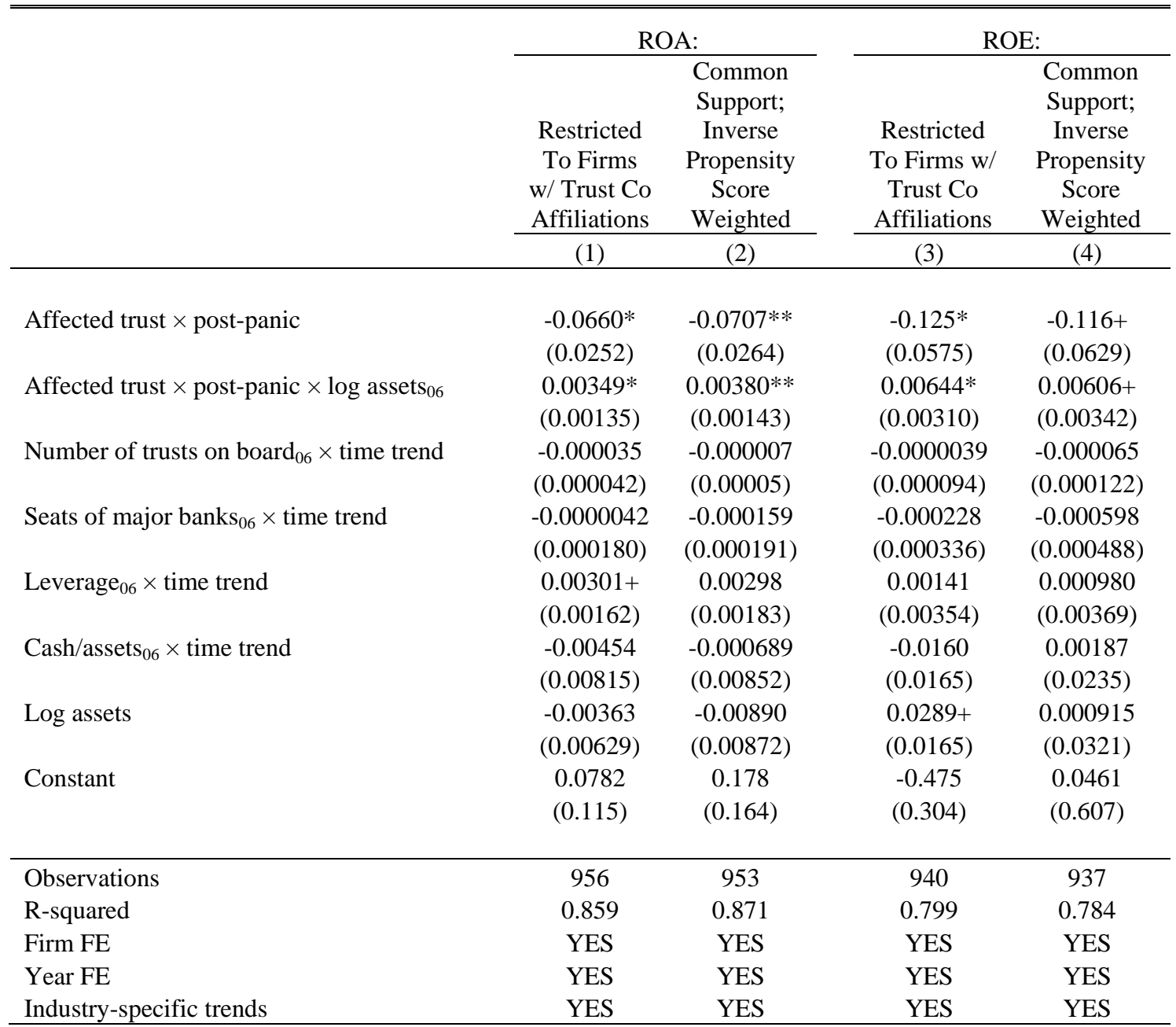

Notes: Standard errors adjusted for clustering by firm in parentheses. ${ }^{* *}, *$, and + indicate significance at the 1,5 and 10 percent level, respectively. In columns (1) and (3), the sample is restricted to firms that have an interlock with at least one trust company. In columns (2) and (4), the sample is restricted to the common support in the propensity to have an affiliation with an affected trust, and the observations are weighted by the inverse of the firms' propensity scores. The log assets interaction in the second row uses the value of assets in 1906. In columns (2) and (4), the added regressors are observed in 1907, in the case of the board variables, or 1906, in the case of the accounting variables, and interacted with a time trend. For a given year, the table uses the annual financial information for all firms with a fiscal year ending between July of that year and June of the following year. 
Table 8

Robustness checks on Dividend and Interest Rates

\begin{tabular}{|c|c|c|c|c|}
\hline & \multicolumn{2}{|c|}{ Dividend Rate: } & \multicolumn{2}{|c|}{ Interest Rate: } \\
\hline & $\begin{array}{c}\text { Restricted } \\
\text { To Firms } \\
\text { w/ Trust Co } \\
\text { Affiliations }\end{array}$ & $\begin{array}{l}\text { Common } \\
\text { Support; } \\
\text { Inverse } \\
\text { Propensity } \\
\text { Score } \\
\text { Weighted } \\
\end{array}$ & $\begin{array}{c}\text { Restricted } \\
\text { To Firms } \\
\text { w/ Trust Co } \\
\text { Affiliations }\end{array}$ & $\begin{array}{c}\text { Common } \\
\text { Support; } \\
\text { Inverse } \\
\text { Propensity } \\
\text { Score } \\
\text { Weighted }\end{array}$ \\
\hline & $(1)$ & $(2)$ & (3) & (4) \\
\hline Affected trust $\times$ post-panic & $\begin{array}{l}-0.0739 * \\
(0.0313)\end{array}$ & $\begin{array}{l}-0.0549 \\
(0.0333)\end{array}$ & $\begin{array}{l}0.0373 * \\
(0.0182)\end{array}$ & $\begin{array}{c}0.0307 \\
(0.0185)\end{array}$ \\
\hline Affected trust $\times$ post-panic $\times \log$ assets $_{06}$ & $\begin{array}{l}0.00397 * \\
(0.00172)\end{array}$ & $\begin{array}{c}0.00310 \\
(0.00189)\end{array}$ & $\begin{array}{c}-0.00197+ \\
(0.000993)\end{array}$ & $\begin{array}{r}-0.00170+ \\
(0.00102)\end{array}$ \\
\hline Number of trusts on board ${ }_{06} \times$ time trend & $\begin{array}{l}-0.000042 \\
(0.00007)\end{array}$ & $\begin{array}{l}-0.000009 \\
(0.000102)\end{array}$ & $\begin{array}{l}-0.000009 \\
(0.000033)\end{array}$ & $\begin{array}{c}0.00002 \\
(0.000035)\end{array}$ \\
\hline Seats of major banks ${ }_{06} \times$ time trend & $\begin{array}{c}0.000084 \\
(0.000287)\end{array}$ & $\begin{array}{l}-0.000099 \\
(0.000383)\end{array}$ & $\begin{array}{c}0.000006 \\
(0.000123)\end{array}$ & $\begin{array}{l}-0.000143 \\
(0.000149)\end{array}$ \\
\hline Leverage $_{06} \times$ time trend & $\begin{array}{l}-0.00473 \\
(0.00287)\end{array}$ & $\begin{array}{l}-0.00456 \\
(0.00370)\end{array}$ & $\begin{array}{l}0.00306^{*} \\
(0.00138)\end{array}$ & $\begin{array}{l}0.00308^{*} \\
(0.00151)\end{array}$ \\
\hline Cash/assets $_{06} \times$ time trend & $\begin{array}{c}-0.00663 \\
(0.0103)\end{array}$ & $\begin{array}{l}0.00843 \\
(0.0163)\end{array}$ & $\begin{array}{l}0.0214^{* *} \\
(0.00779)\end{array}$ & $\begin{array}{c}0.0155 \\
(0.0100)\end{array}$ \\
\hline Log assets & $\begin{array}{c}0.0102 \\
(0.0107)\end{array}$ & $\begin{array}{c}-0.00313 \\
(0.0189)\end{array}$ & $\begin{array}{l}-0.00942 * \\
(0.00472)\end{array}$ & $\begin{array}{l}-0.0166+ \\
(0.00851)\end{array}$ \\
\hline Constant & $\begin{array}{l}-0.161 \\
(0.201)\end{array}$ & $\begin{array}{l}0.0732 \\
(0.359)\end{array}$ & $\begin{array}{c}0.211^{*} \\
(0.0854)\end{array}$ & $\begin{array}{c}0.349 * \\
(0.158)\end{array}$ \\
\hline Observations & 960 & 967 & 685 & 706 \\
\hline R-squared & 0.885 & 0.887 & 0.705 & 0.778 \\
\hline Firm FE & YES & YES & YES & YES \\
\hline Year FE & YES & YES & YES & YES \\
\hline Industry-specific trends & YES & YES & YES & YES \\
\hline
\end{tabular}

Notes: Standard errors adjusted for clustering by firm in parentheses. ${ }^{* *}, *$, and + indicate significance at the 1,5 and 10 percent level, respectively. In columns (1) and (3), the sample is restricted to firms that have an interlock with at least one trust company. In columns (2) and (4), the sample is restricted to the common support in the propensity to have an affiliation with an affected trust, and the observations are weighted by the inverse of the firms' propensity scores. The log assets interaction in the second row uses the value of assets in 1906. In columns (2) and (4), the added regressors are observed in 1907, in the case of the board variables, or 1906, in the case of the accounting variables, and interacted with a time trend. For a given year, the table uses the annual financial information for all firms with a fiscal year ending between July of that year and June of the following year. 
Table 9

Comparison of Industrials vs. Railroads

\begin{tabular}{|c|c|c|c|c|}
\hline & ROA & ROE & $\begin{array}{c}\text { Interest } \\
\text { rate }\end{array}$ & $\begin{array}{c}\text { Dividend } \\
\text { rate }\end{array}$ \\
\hline & $(1)$ & $(2)$ & (3) & (4) \\
\hline Affected trust $\times$ post-panic $\times$ Industrial & $\begin{array}{c}-0.00737+ \\
(0.00396)\end{array}$ & $\begin{array}{c}-0.0249 * * \\
(0.00725)\end{array}$ & $\begin{array}{c}0.00638 * * \\
(0.00233)\end{array}$ & $\begin{array}{c}-0.00602 \\
(0.00410)\end{array}$ \\
\hline Affected trust $\times$ post-panic $\times$ Railroad & $\begin{array}{c}0.00250 \\
(0.00230)\end{array}$ & $\begin{array}{c}0.00470 \\
(0.00537)\end{array}$ & $\begin{array}{l}0.000047 \\
(0.00185)\end{array}$ & $\begin{array}{c}0.00348 \\
(0.00377)\end{array}$ \\
\hline Observations & 1,063 & 1,047 & 745 & 1,066 \\
\hline R-squared & 0.872 & 0.804 & 0.696 & 0.888 \\
\hline Firm FE & YES & YES & YES & YES \\
\hline Year FE & YES & YES & YES & YES \\
\hline Firm 1906 characteristics $\times$ trends & YES & YES & YES & YES \\
\hline Industry-specific trends & YES & YES & YES & YES \\
\hline
\end{tabular}

Notes: Standard errors adjusted for clustering by firm in parentheses. **, *, and + indicate significance at the 1, 5 and 10 percent level, respectively. Regressions also include contemporaneous log assets and a constant term. For a given year, the table uses the annual financial information for all firms with a fiscal year ending between July of that year and June of the following year.

Table 10

Assessing the effect of unobservable characteristics: The 1903-04 Recession

\begin{tabular}{|c|c|c|c|c|}
\hline & ROA & ROE & $\begin{array}{c}\text { Dividend } \\
\text { rate }\end{array}$ & $\begin{array}{c}\text { Interest } \\
\text { rate }\end{array}$ \\
\hline & $(1)$ & (2) & (3) & (4) \\
\hline Affected trust in $1907 \times 1903-04$ & $\begin{array}{c}0.0334 \\
(0.0424)\end{array}$ & $\begin{array}{c}0.0535 \\
(0.115)\end{array}$ & $\begin{array}{c}0.0493+ \\
(0.0249)\end{array}$ & $\begin{array}{c}-0.0374 \\
(0.0272)\end{array}$ \\
\hline Affected trust in $1907 \times 1903-04 \times$ logassets'04 & $\begin{array}{l}-0.00190 \\
(0.00223)\end{array}$ & $\begin{array}{l}-0.00326 \\
(0.00603)\end{array}$ & $\begin{array}{l}-0.00280 * \\
(0.00130)\end{array}$ & $\begin{array}{c}0.00208 \\
(0.00147)\end{array}$ \\
\hline Observations & 370 & 370 & 370 & 244 \\
\hline R-squared & 0.932 & 0.863 & 0.933 & 0.882 \\
\hline Firm FE & YES & YES & YES & YES \\
\hline Year FE & YES & YES & YES & YES \\
\hline
\end{tabular}




\section{Appendix: For Online Publication A1. Data Appendix}

\section{Trust Companies}

Data on trust company balance sheets and deposits collected from quarterly reports submitted to the New York Superintendent of Banks, as reported in the trade publication Trust Companies. The dates chosen for the data presented in Figure 2 for the change in deposits-August 22 as a beginning and December 19, 1907 as the end-represent the two call dates closest to the panic. The data used in the regressions presented in Table 1 are collected from quarterly statements presented in Trust Companies, except for firm age, which was defined as 1907 minus the year of the company's incorporation, which was obtained from the Annual Report of the Superintendent of Banks Relative to Savings Banks, Trust Companies, Safe Deposit Companies, and Miscellaneous Corporations (1908).

Summary statistics for the variables used in the regression are presented in Table A1. Means are presented for all trust companies, and then separately for those with and without a connection to the scandal (whether direct or indirect). Standard deviations are given in brackets.

Table A1

Summary Statistics, New York Trust Companies

\begin{tabular}{lccc}
\hline \hline & & $\begin{array}{c}\text { Trust Co's w/ } \\
\text { No Connection } \\
\text { to Scandal } \\
(\mathrm{n}=30)\end{array}$ & $\begin{array}{c}\text { Trust } \\
\text { Direct or } \\
\text { Indirect } \\
\text { Connection to } \\
\text { Scandal } \\
\text { (n=8) }\end{array}$ \\
\hline Net Worth / Assets & 0.215 & 0.224 & 0.185 \\
(n = 38) & {$[0.127]$} & {$[0.137]$} & {$[0.084]$} \\
Cash / Checkable Deposits & 0.042 & 0.040 & 0.049 \\
Stock and Bond Investments / Assets & {$[0.013]$} & {$[0.012]$} & {$[0.016]$} \\
& 0.237 & 0.242 & 0.218 \\
Log(Total Assets) & {$[0.154]$} & {$[0.168]$} & {$[0.095]$} \\
Log(Firm Age) & 16.692 & 16.664 & 16.797 \\
& {$[1.151]$} & {$[1.182]$} & {$[1.092]$} \\
Uptown Headquarters & 2.233 & 2.419 & 2.014 \\
& {$[1.155]$} & {$[1.149]$} & {$[1.198]$} \\
& 0.263 & 0.233 & 0.375 \\
& {$[0.446]$} & {$[0.430]$} & {$[0.518]$} \\
\hline
\end{tabular}

Trust companies with a connection to the scandal were somewhat younger and had a lower proportion of their assets invested in stocks and bonds (usually representing customer assets in trust accounts). However, they were larger, and held somewhat higher cash reserves. They also had somewhat lower levels of capital relative to their assets.

Stock Price Data 
To calculate weekly returns at the onset of the Panic of 1907, we collect stock price and dividend data for the 18 weeks from the last week in August to the last week in December of 1907. For each firm in our sample, we search for the Friday closing price of common shares in The New York Times Stock Quote tables published in Saturday's newspaper. Although most of the information corresponds to prices on the NYSE, we expand the sample by collecting transaction prices from the Boston, Chicago, Philadelphia, and Pittsburg Stock Exchanges. Since the market was fairly illiquid at that time, we also search for Saturday's closing price in the Stock Quote table published in Sunday's newspaper. We obtain a total of 1,170 non-missing Friday prices, and we increase the number of observations to 1,523 by filling in missing Friday data with Saturday's prices. Since this procedure does not alter our results but increases our sample size, we use the filled in data.

To calculate returns, the stock price needs to be adjusted by the dividend payout when shares go exdividend. We obtain information on announced dividend payouts (both for regular and extra cash dividends) and ex-dividend dates from the Declared Dividends table published each Sunday in The New York Times. Because the dividend payouts were mostly quoted as a percentage of the book value of shares, we use par value of common shares, collected from the Moody's Manuals for the year 1907, to determine the dividend dollar amount. ${ }^{65}$ We also obtain from Moody's the number of shares outstanding for each company, calculated as the book value of common shares dividend by their par value, which allows calculating value-weighted returns. We are more likely to observe stock returns for large firms, but no other observable firm characteristic is a strong predictor of availability of stock price information.

Correctly measured returns should also adjust stock prices in the event of a stock split. Identifying stock splits during the last four months of 1907 is difficult within our data because we only obtain the number of shares outstanding on an annual basis. To gauge whether ignoring stock splits introduces a large bias in the returns, we collect information on the number of shares outstanding for the weeks ended on September $7^{\text {th }}$ and December $28^{\text {th }}$ from week-end summary Stock Quotes tables published in The New York Times on the following Mondays. The tables report the value of the capital stock outstanding and the par value of shares, from which we calculate the number of common shares for the 56 firms included on both dates. Of these firms, 86 percent had no change in the absolute number of shares. For the other firms, the change was never higher than 0.74 percent of the shares outstanding in September. Thus, there is no evidence that the firms in our sample experienced a stock split during the period under study.

The industry-adjusted return on firm $i$ from week $t-1$ to week $t$ is computed as:

$$
R_{i, t}^{a d j}=R_{i, t}-\sum_{j=1}^{J} w_{j, t-1} R_{j, t}
$$

where $R_{i, t}$ is the total return on firm $i$ from week $t-1$ to $t$ calculated as $R_{i, t}=\left[\left(P_{i, t}+d_{i, t}\right)-P_{i, t-1}\right] / P_{i, t-1}$, the $J$ firms in the same industry classification as firm $i$ are used to calculate the industry return, and $w_{j, t-1}$ is the market capitalization weight of firm $j$ within the industry portfolio at the end of the previous period. Given the small sample size of our data, we can only use one-digit SIC to obtain enough observations within each industry. We restrict the empirical analysis on SIC 2 to SIC 4 because we only have price data for at most two firms in other industries. To calculate the industry return, we use all firms in the industry in a given week, regardless of whether the same firm also has available returns in surrounding weeks. Using an equal-weighted industry index rather than a value-weighted measure does not affect our findings.

Cumulative returns for a window of weeks $[-k, k]$ centered on the onset of the panic are calculated as:

\footnotetext{
${ }^{65}$ We verify the par values using the weekly summary Stock Quotes tables published in The New York Times.
} 


$$
\text { Industry - Adjusted Cum. Return }{ }_{i}=\sum_{t=-k}^{t=k} R_{i, t}^{a d j}
$$

We also present results with unadjusted returns, which are simply based on the cross-sectional variation in returns. This is equivalent to using to a market-adjusted-return model, which assumes that $\alpha=0$ and $\beta=1$ for every share (Campbell, Lo and MacKinlay, 1997). Because the event date is the same for all firms in the sample, subtracting the overall market return from the weekly individual stock return for all firms would only affect the constant term of the regression.

A limitation of historical stock market data is that securities markets were fairly illiquid. Some companies rarely traded during the four months in our sample, and are therefore not part of our analysis. Others traded frequently, but may not have had a transaction at the end of every week. To be able to cumulate returns when some returns are missing within the event window, we assume no price changes in weeks for which prices are missing, under the restriction that at least one nonmissing return was observed during the event window $[-k, k]$. For example, for the week centered on October 25, we observe returns for all three Fridays in the event window for 77 firms. For another 14 firms we observe either one or two returns. We assume that the missing percentage change in price was zero in these 14 cases. However, we restrict the data further to the firms for which there is at least one non-missing return at either end of the event window, which drops four firms from the analysis. ${ }^{66}$ Restricting the sample to industries with cumulative returns for more than nine firms eliminates another two firms. In this manner, our final sample contains a total of 85 firms with cumulative returns for the period $[-1,1]$. Results are overall robust to using only observations with non-missing returns in any week within the window.

\section{Accounting Data - Non-financial Companies}

All accounting data were collected from Moody's Manuals of Railroads and Corporation Securities. Financial statements varied considerably across firms and over time. The accounting data are quite noisy, and in order to eliminate the potential for outliers to exert a significant influence on the estimation, all variables are trimmed at the top and bottom one percent.

One important aspect in which companies' statements differed was in the dates of their fiscal year end. For example, among the industrial firms in 1907, 25 percent had a fiscal year end of June, 35 percent had a fiscal year end of December, and the remaining firms were roughly evenly divided among the other months of the year. We designated the accounting data for a fiscal year as being for that same year in our dataset if the fiscal year end was in July or later. If the fiscal year ended in June or earlier, we designated it as being from the previous year.

The definitions of the variables utilized in the empirical analysis, along with some discussion of how the underlying data was coded, are presented below:

Return on Assets (ROA): net income/total assets. The definition of net income varied somewhat across firms; for example some industrials, and most railroads, reported no depreciation expense and may not have recognized depreciation in their accounting.

Return on Equity (ROE): net income/common shareholders' equity, where shareholders' equity includes the book value of the common shares as well as the firm's 'surplus' (retained earnings). In some cases common and preferred shares were reported as a single item on the balance sheet, and the exact amounts of each had to be computed from disclosures of the number of shares outstanding and the par value of the shares. (None of the sample firms in this period had issued zero-par shares.) This is not available for one firm for which ROA is

\footnotetext{
${ }^{66}$ To be precise, consider the case of cumulative returns over [-4,4]. If we observed no non-missing return from week 3 onwards, for example, we would not include this firm in the sample.
} 
available (accounting for the difference in observations in regressions for the two variables), because it did not disclose its surplus separately from other accounts.

Dividend rate: dividends paid out on common stock/book value of common stock. In general this was quite reliably reported; however in some cases only total dividends (common plus preferred) were disclosed and the amount of common dividends had to be calculated based on separate disclosures of the dividend rate and of the number of shares outstanding and the par value of the shares.

Interest rate: total interest payments/long-term debt. For most firms, long-term debt was simply 'bonded debt.' For many firms, this measure is not available because leverage is zero (140 firm-year observations) or the income statement reports it together with other expenses (e.g., "other expenses"). A relatively large fraction of firms disclosed "fixed charges" rather than interest, which in theory could include payments on leases and other related expenses. For those firms, the interest rate in our dataset is actually fixed charges/debt. With regard to long-term debt, many firms reported liabilities of a somewhat ambiguous character; these included obligations to parent or subsidiary companies. In addition, some firms disclosed liabilities that could have represented long-term debt, such as loans, together with current liabilities, such as accounts payable, as a single balance sheet item. The results presented in the paper are robust to the use of an alternative measure of the interest rate where the denominator is defined more broadly to include those items; statistical precision, however, is reduced from the noise that is introduced into the variable.

Leverage ratio: long-term debt/total assets. See the discussion of the interest rate variable.

Cash to assets ratio: cash/total assets. Although many firms reported securities on their balance sheet, few of these seemed to constitute 'cash equivalents' and instead were likely securities held for the purposes of controlling other enterprises. The variable therefore includes only cash in its numerator.

Firm age: current year minus the year of the oldest date of incorporation for the firm found in Moody's.

Industry codes: obtained from Chandler's (1990) designations of his sample of firms. For those firms not included in Chandler's sample, SIC codes were assigned based on the descriptions of their operations in Moody's.

\section{Board Data, Director Names \& Matching Procedure}

We obtain information on the names of officers and directors of all railroads and industrial firms from the Moody's Manual of Railroads and Corporation Securities of 1907. We start with a sample of all NYSE-listed firms in that year, a total of 115 industrials and 66 railroads. When we restrict the sample to the 125 firms for which we have accounting data in 1906, the dataset contains a total of 2,236 observations, of which 70.5 percent are directors, and the balance are officers and other executives. Thus, our final sample has 783 names of directors of industrial firms and 793 names of directors of railroads. To be able to identify bankers, we obtain the names of 4,266 directors of 274 commercial banks and trust companies in the three major financial centers, New York, Boston, and Chicago, from the Rand McNally Bankers’ Directory of 1907.

We match on names across these samples to identify connections between non-financial firms and banks, as well as the connections amongst these two types of institutions. We follow a thorough procedure to clean the collected names and ensure the accuracy of the matches. First, we ensure that matching is not hampered by transcription errors or inconsistencies in the source material. Since the management of financial and non-financial firms was relatively stable over time, management data collected from the 1905 and 1909 Moody's Manuals and McNally's Directories aided the cleaning 
process. ${ }^{67}$ We start by verifying the transcription of a given full name (defined by first and middle name, last name, and suffix) by finding its presence in the same company in the years surrounding 1907. For names that do not match perfectly, we use an algorithm to find approximate matches in names in surrounding years. This procedure identifies cases in which only one letter of the entire name differs across sources. In this manner, we are able to identify transcription errors and inconsistencies in the source materials. Finally, unusual first and middle names, defined as those not found in the top 500 names of males born in the United States in 1880 as reported by the Social Security Administration, as well as unique names that were not found in the adjacent years, are also re-checked against the source materials for 1907 in order to identify and correct transcription errors.

Most inconsistencies in the source materials result from alternative spellings of names that would hinder our ability to correctly identify the same individual across firms or years. Many of these inconsistencies are resolved by a set of rules that we developed to standardize names. We use these rules only to address issues of capitalization, spacing, hyphens, and apostrophes. As an example, "DuPont" was chosen to represent the following variations, all of which appeared in source materials: "du Pont," "Dupont," "duPont,” and "Du Pont.” For the remaining inconsistencies, alternative sourcessuch as the Directories of Directors, biographies, newspapers, and various historical books, are used to determine whether two names represent the same person. When we find that two names refer to the same individual, we resolve the inconsistency by either using the version used more frequently or the chronologically most recent spelling.

For the purpose of determining interlocks between the boards of financial and non-financial firms, we would ideally use each director's full name. However, the Moody's Manuals report only initials for first and middle name for 37.2 percent of the recorded directors. Thus, we are constrained to matching on names using only first initial, middle initial, last name, and suffix. This data restriction is problematic since it will lead to overestimating interlocks across boards whenever two individuals who share a last name have different first and middle names with the same initials. To address this potential source of overmatching, we use data on names across firms, banks, and years to identify cases where two or more individuals share the same first initial, middle initial, last name, and suffix, but where there is variation in their full names for at least one of all their observations. We then use information from Directories of Directors, newspaper articles, annual reports, biographies, and other sources to provide first and middle names for these cases. Using this information we develop a new full name variable, fullname_d, which separately identifies individuals that would otherwise collapse to one person if we were to use the uncorrected first and middle initials. For example, Walter $\mathrm{H}$ Taylor from Norfolk \& Western, William H Taylor from Bowling Green Trust Company and W H Taylor from American Writing Paper would all be incorrectly identified as the same person using only first and middle name initials. The use of additional sources allows determining whether $\mathrm{W} \mathrm{H}$ Taylor was Walter, William, or a third person altogether (he was William). As we discuss below, this corrected name variable consistently identifies individuals across samples and years.

Interlocks between non-financial firms and commercial banks, as well as across firms within each of these samples, are found by identifying exact matches in the variable fullname_d. Out of 1,576 directors of the 125 non-financials with complete accounting data, 648 were found also to be directors of commercial banks. Since a person can sit on several boards, these directors form 1,341 interlocks between non-financials and commercial banks. On average, each non-financial firm was connected through directors to 10.7 commercial banks and trust companies, and to 9.4 New York City commercial banks and trust companies in 1907.

Even after carefully cleaning the data, it is possible that our sample could suffer from some degree of overmatching. For example, two individuals may have shared the same full name. A potentially

\footnotetext{
${ }^{67}$ To provide a longer run view of the connections between financial and non-financial firms, as in Figure 3 in the paper, we collect similar management data in 1911 and 1913. We use exactly the same procedure described in this section to clean and accurately match the names of directors across companies and years.
} 
more common problem is that we may only observe initials for first and middle name across all samples and years in our date. Conditional on the same last name and suffix, we would not be able to identify these cases as potentially problematic, in the way described for the example for W H Taylor above. Algorithms based on the "sound" of names that are commonly used to determine the likelihood of a correct match when researchers match on names would not be of use in our case. Instead, we assess the reliability of our matching procedure by using an external source. During the first few decades of the twentieth century, it is possible to obtain Directories of Directors for various cities. These directories are compendia of businessmen and their board affiliations. For example, the New York City directory claims to contain "a complete alphabetical list of Directors or Trustees having New York City addresses, followed by the names of Companies with which each is connected.” The publishers and coverage do change somewhat across cities and over time, but the presence of most of the individuals in our sample in these volumes suggests that their reporting is quite reliable, at least for prominent individuals.

To give a sense of the validity of our procedure, we look for external verification using the entire sample of 181 railroad and industrial firms, which includes those for which no accounting data is available. Using our variable fullname_d, we match the 2,119 directors of these non-financials to the 4,264 directors of commercial banks and trust companies in 1907. This results in 381 individuals creating an interlock between at least one non-financial and one financial firm. Of these, we were not able to find 6.6 percent of the observations in the Directory of Directors volumes. For the 353 directors that we were able to locate in those volumes, there were only three false matches, all due to different individuals with identical names. That is, for only 0.85 percent of the interlocks, our matching mechanism incorrectly identified different individuals as the same person. ${ }^{68}$ For the 350 individuals correctly identified as creating an interlock, on average the Directories of Directors list them on 88 percent of all the boards that are identified in our data. Inspection of the few cases that did match suggests that this was mostly due to the difference in the timing and coverage between the Moody's Manuals and the Directories of Directors. ${ }^{69}$ Thus, we conclude that our matching procedure is highly accurate.

\section{A2. Results Appendix}

\section{Main Specifications}

In this section, we address additional sources of concern regarding our results by presenting alternative robustness checks to the main specifications in the paper. The results of these specifications are presented in Table A2.

One issue might be that the balance sheet variables included as controls in the regressions, and interacted with time trends, were the values from 1906, perhaps too close to the onset of the panic. Instead, it may be preferable to use the earliest available values. Unfortunately balance sheet data are not available for many companies for the years 1903 and before. Therefore, we use the values from 1904 in the regressions, although data for even that year are not available for many companies. For example, using 1904 values would result in the loss of 244 observations in the profitability regressions. In order to keep the sample consistent, we substitute the value of assets from 1905 in cases in which the 1904 value is not available (this is available for 200 of the 244 observations with missing 1904 data) and, where necessary, the 1906 values (which are available for the final 44 observations). The first two rows of Table A2 present the results of specifications identical to those of columns (2) and (4) of Tables 6 and 7, with 1904 values (or the earliest available) for leverage and

\footnotetext{
${ }^{68}$ Of course, we correct the fullname_d variable for these three individuals based on this additional information. Thus, the data we use to determine connections between financial and non-financial firms in the paper is highly reliable.

${ }^{69}$ For example, the 1906 Directory of Directors would not list a commercial bank established in 1907, but this firm would appear in the Rand McNally Banker's Directory for 1907.
} 
cash interacted with time trends, rather than the 1906 values.

Another potential source of concern could be that some firms were growing rapidly and perhaps unsustainably in the years prior to the panic, which led them to be particularly vulnerable when the panic began. Although our earlier results demonstrated that there was no large or statistically significant difference in the trend in assets between firms with and without affiliations with affected trust companies, in part B of the table we explicitly include the average growth rate of assets in the years 1903-06 in the regression, interacted with a time trend. Our growth rate of assets variable is available (in the sense that there is at least one year of assets growth data) for companies accounting for all but 57 of the observations in the profitability regressions; thus the sample contracts by 57 observations in those regressions, and by 38 observations in the interest rate regression. Industryspecific trends are also included in the regression.

Finally, one might be concerned that the specification with the assets interaction we have relied upon thus far might not actually be the relevant characteristic for determining the degree to which firms would be exposed to financial frictions. Arguably, firm age would also capture the degree to which a firm was "known" to participants in financial markets, as older firms would likely have longer track records as issuers of securities or borrowers. The final two rows of the table present regressions in which the assets interaction is replace with an interaction with log age, in specifications identical to those of columns (1) and (3) of Tables 6 and 7.

In general, the results of each of these alternative specifications are similar to those of the baseline specification they correspond to. In each case, the estimates for one of the four dependent variables of interest become statistically insignificant. But in every case, the signs and the magnitudes remain relatively similar. We argue that our results are not the product of misspecification.

Table A2

Further Robustness Checks

\begin{tabular}{|c|c|c|c|c|}
\hline & ROA & ROE & $\begin{array}{c}\text { Dividend } \\
\text { Rate } \\
\end{array}$ & $\begin{array}{c}\text { Interest } \\
\text { Rate }\end{array}$ \\
\hline \multicolumn{5}{|l|}{$\begin{array}{l}\text { A. } 1904 \text { balance sheet values interacted w/ } \\
\text { trends }\end{array}$} \\
\hline Affected trust $\times$ post-panic & $\begin{array}{c}-0.0661 * * \\
(0.0244)\end{array}$ & $\begin{array}{c}-0.117^{*} \\
(0.0557)\end{array}$ & $\begin{array}{c}-0.0603+ \\
(0.0331)\end{array}$ & $\begin{array}{c}0.0273 \\
(0.0181)\end{array}$ \\
\hline Affected trust $\times$ post-panic $\times \log$ assets & $\begin{array}{c}0.00355^{* *} \\
(0.00131)\end{array}$ & $\begin{array}{l}0.00604 * \\
(0.00301)\end{array}$ & $\begin{array}{l}0.00328+ \\
(0.00182)\end{array}$ & $\begin{array}{l}-0.00136 \\
(0.00101)\end{array}$ \\
\hline \multicolumn{5}{|c|}{ B. Growth of assets '03-'06 x trend, industry trends } \\
\hline Affected trust $\times$ post-panic & $\begin{array}{c}-0.0449+ \\
(0.0247)\end{array}$ & $\begin{array}{l}-0.0858 \\
(0.0556)\end{array}$ & $\begin{array}{c}-0.0536+ \\
(0.0312)\end{array}$ & $\begin{array}{c}0.0297+ \\
(0.0154)\end{array}$ \\
\hline Affected trust $\times$ post-panic $\times$ log assets & $\begin{array}{l}0.00241+ \\
(0.00132)\end{array}$ & $\begin{array}{c}0.00438 \\
(0.00300)\end{array}$ & $\begin{array}{c}0.00280 \\
(0.00169)\end{array}$ & $\begin{array}{c}-0.00154+ \\
(0.000831)\end{array}$ \\
\hline C. Age rather than assets interaction & & & & \\
\hline Affected trust $\times$ post-panic & $\begin{array}{l}-0.00815 \\
(0.00608)\end{array}$ & $\begin{array}{c}-0.0276^{* *} \\
(0.0105)\end{array}$ & $\begin{array}{c}-0.0121+ \\
(0.00646)\end{array}$ & $\begin{array}{l}0.00676 * \\
(0.00296)\end{array}$ \\
\hline Affected trust $\times$ post-panic $\times$ log age & $\begin{array}{l}0.00305^{+} \\
(0.00180)\end{array}$ & $\begin{array}{l}0.00822 * \\
(0.00334)\end{array}$ & $\begin{array}{l}0.00374+ \\
(0.00206)\end{array}$ & $\begin{array}{c}-0.00161+ \\
(0.000846)\end{array}$ \\
\hline
\end{tabular}

\section{3-04 Recession}

One potential source of concern regarding the test of firm performance in the 1903-04 recession could be that in the years between 1904 and 1907, some NYSE-listed firms may have experienced events that made them more vulnerable to the effects of a shock then they had been earlier. Our 
placebo test using the earlier recession would be invalidated if the fundamental characteristics of non-financial firms changed substantially in the four-year period between financial crises. Two important potential sources of change are antitrust prosecutions by the federal government, and mergers and acquisitions.

Beginning with the Northern Securities case, which was initiated in 1902 and decided in 1904, the Roosevelt Administration initiated a number of antitrust cases that may have weakened some NYSE firms. In order to identify the firms that were subject to antitrust prosecutions, we compiled a list of all federal court decisions citing the Sherman Antitrust Act issued between 1904 and 1912, and searched for all corporate defendants named in the decisions. Many of these cases were initiated against firms that were not listed on the NYSE, such as Standard Oil and its various subsidiaries. In total, 23 NYSE firms were subject to federal antitrust cases decided during those years.

Mergers or major acquisitions are a related issue. The wave of mergers that swept through the U.S. economy in the late nineteenth century was underway until around 1904, and firms may have undertaken mergers that weakened their balance sheets prior to 1907. Only 3 firms within our sample were part of mergers that resulted in an increase in their total assets of more than $30 \%$. It is likely that firms first appeared within our sample as the outcome of a merger, so that no pre-merger data are generally available.

We address the possibility that antitrust cases and mergers made firms vulnerable to the 1907 panic in a way that they were not during the 1904 panic by deleting all observations from firms that were subject to an antitrust case (irrespective of the outcome) or were part of a merger and re-estimating the specifications for 1907 and 1903-04. The results are presented in Table A3.

Table A3

Firms involved in Mergers and Antitrust Cases Deleted

\begin{tabular}{lcccc}
\hline \hline & $(1)$ & $(2)$ & $(3)$ & $\begin{array}{c}(4) \\
\text { Interest rate }\end{array}$ \\
& ROA & ROE & Dividend rate & \\
& & & & \\
Affected trust $\times$ post-panic & $-0.0821^{*}$ & $-0.184^{* *}$ & $-0.105^{*}$ & $0.0364^{*}$ \\
& $(0.0317)$ & $(0.0679)$ & $(0.0526)$ & $(0.0152)$ \\
Affected trust $\times$ post panic $\times$ logassets'06 & $0.00449^{*}$ & $0.00983^{*}$ & $0.00573^{*}$ & $-0.00185^{*}$ \\
& $(0.00173)$ & $(0.00375)$ & $(0.00295)$ & $(0.000839)$ \\
Observations & & & & 591 \\
R-squared & 839 & 824 & 0.877 & 0.693 \\
Firm FE & 0.857 & 0.779 & YES & YES \\
Year FE & YES & YES & YES & YES \\
\hline
\end{tabular}

Standard errors adjusted for clustering by firm in parentheses. ${ }^{* *},{ }^{*}$, and + indicate significance at the 1,5 and 10 percent level, respectively. Regressions also include contemporaneous log assets and a constant term.

The results clearly show that deleting these firms strengthens, rather than reduces, the estimated effects of the panic. The reasons for this are intuitive: the most profitable, successful and robust firms were likely the subject of antitrust cases, and even successful prosecutions of these firms was not enough to radically change their dominant market positions. These firms were also less sensitive to the loss of a lender or the tarnished reputation of one of their directors. 